\title{
OBRAS E INFRAESTRUCTURAS PORTUARIAS EN LAS ISLAS CHAFARINAS
}

\author{
FRANCISCO NARVÁEZ LÓPEZ \\ Investigador
}

\section{PROYECTOS MILITARES PARA EL PUERTO DE CHAFARINAS}

Desde muy antiguo, las car tas náuticas señalaban a Chaf arinas como un privilegiado fondeadero, pues su ensenada cóncava hacia el sur venía siendo utilizada durante siglos por los na vegantes (especialmente los que desde Argelia, Italia y Marsella seguían la ruta del Estrecho) para proteger a sus buques y embarcaciones de los temporales del primer cuadrante, es decir, los de levante. En el año 1856 fueron 150 barcos, españoles y extranjer os, los que tuvier on que buscar refugio y fondear en las Chafarinas para protegerse de los vientos y temporales ${ }^{1}$.

La falta de un puer to en Melilla y el hec ho que las Chafarinas fueran el único fondeadero natural que existía entre Argelia (Orán) y Gibraltar, hizo que desde muy pronto se planteara mejorar su puerto natural. Esta necesidad, aparecía como imperiosa a finales del siglo XIX y principios del XX debido a los intereses de España en la zona y a la inexistencia de un punto de apoyo para el fondeadero, dado que Cabo del Agua aún no estaba en manos españolas, en caso de conflictos con los rifeños. Treinta y cinco años más tarde, con motivo de la guerra de Margallo, se harían realidad estas previsiones, pues los buques militares que vinieron a Melilla, tuvieron que buscar refugio en las Chafar inas, pues los temporales que azotaban la zona pusier on en peligro a los navíos, sus tropas y mercancías.

1 Memoria presentada por el Comandante de Ingenier os D. José María Aparici y Biedma en apoyo de que no sean abandonadas las islas Chafarinas. 




Plano del fondeadero de las islas Chafarinas en dos vistas levantado por el Almirante de Navío D. José Espin, 1870-80. Servicio Geográfico del Ejército.

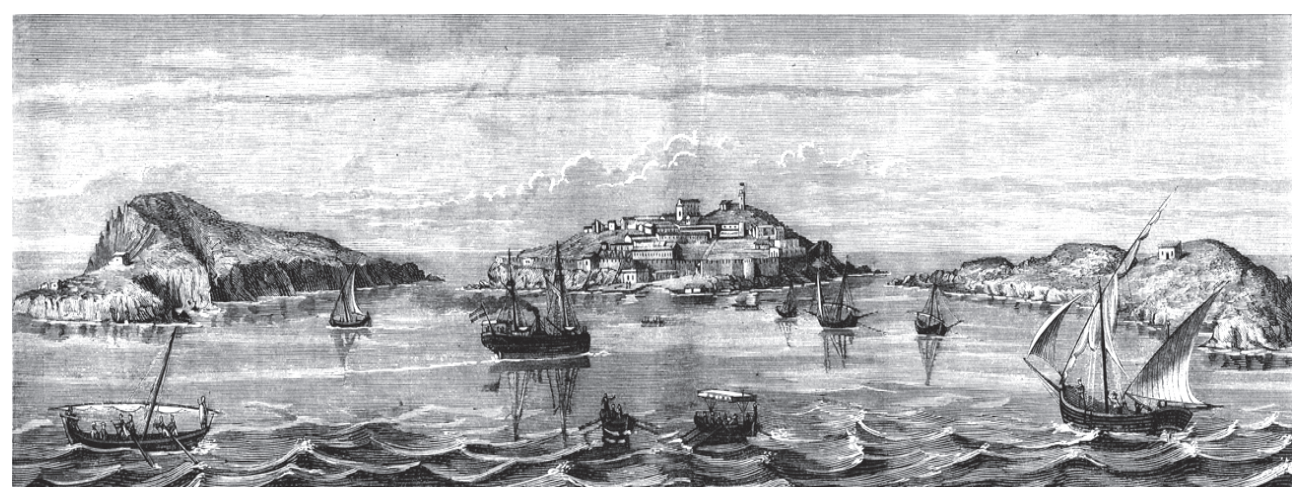

Vista general de las islas desde las costas de Cabo del Agua. La Ilustración Nacional, 8 de noviembre de 1893. 
No serían sólo los españoles los que se plantear on las posibilidades de un puerto en estas islas, pues oficiales franceses e ingleses valoraron la bondad del fondeadero e incluso, estos últimos, estudiaron proyectos para construir un puerto en las Chafarinas.

\section{a) El proyecto de José María Aparici y Juan Manuel Lombera.}

Aunque en 1855 una comisión visitó las Chafirinas y en su informe propuso la unión de las islas de Isabel II y Re y mediante una escollera, con un presupuesto aproximado de $250.000 \mathrm{r}$ eales, lo cier to es que los pr imeros estudios serios sobre el puerto nacieron de la inquietud personal de José María Aparici. Este comandante de Ingenieros de Melilla y Chafarinas redactó el 2 de enero de 1858 el primer anteproyecto de puerto, al que acompañaba una Memor ia descriptiva de los aspectos más r elevantes del fondeadero: fondos, entradas y salidas, vientos y mareas, temporales y sus efectos,necesidad de las obras,cierre del freo chico y dirección del muelle, rompeolas en la Laja, muelle de descarga, torre vigía y presupuesto. En la Memoria, Aparici afirmaba que el fondeadero de 6 a 15 brazas de agua situado entre las islas del Rey e Isabel II,según sus estudios, podría convertirse en un magnífico puerto con sólo cerrar el freo que las separaba, obra que a su juicio no pr esentaba dificultad de ninguna clase ni suponía mucho gasto.

La Memoria fue presentada a la superioridad, la cual mandó redactar un proyecto de defensa de las islas a una comisión formada por el teniente coronel Juan Manuel Lombera y el comandante J osé María Aparici, los cuales incluyeron, entre sus estudios y pr opuestas, la cuestión del puer to, redactando y firmando el 8 de septiembre de 1859 el Proyecto de las obras que han de hacerse en el puerto de las Islas Chafarinas, al que acompañaron una Memoria con los aspectos técnicos y presupuestarios.

Las obras más impor tantes de este pro yecto ${ }^{2}$, que se alimentaba en sus líneas principales del proyecto de Aparici, eran las siguientes:

1. Muelle de unión de las islas de Isabel II y Rey, con una longitud de 660 pies castellanos (201.168 m.), una anchura de 48 pies (14.6304 m.), dividido en dos andenes. El muelle estaba proyectado con sillares artifi-

2 APARICI, José María (1880). Proyecto de mejora del puerto de Chafarinas en la costa de Áfri ica. Madrid: Imprenta del Memorial de Ingenieros. 
ciales de 6 × 6 × 12,77 pies de hor migón hidráulico, desechándose la escollera a piedra perdida, a pesar de ab undar dicho material en las islas, por no ofrecer garantías suficientes. El muelle contaba con un muro exterior, un muro central y un m uro interior, que tenían una triple finalidad: servir de muelle de descarga, de paso entre ambas islas y evitar la entrada del mar en el fondeader o. El plazo de ejecución de esta parte del proyecto se estimaba en unos cuatro años, con unos doscientos operarios.

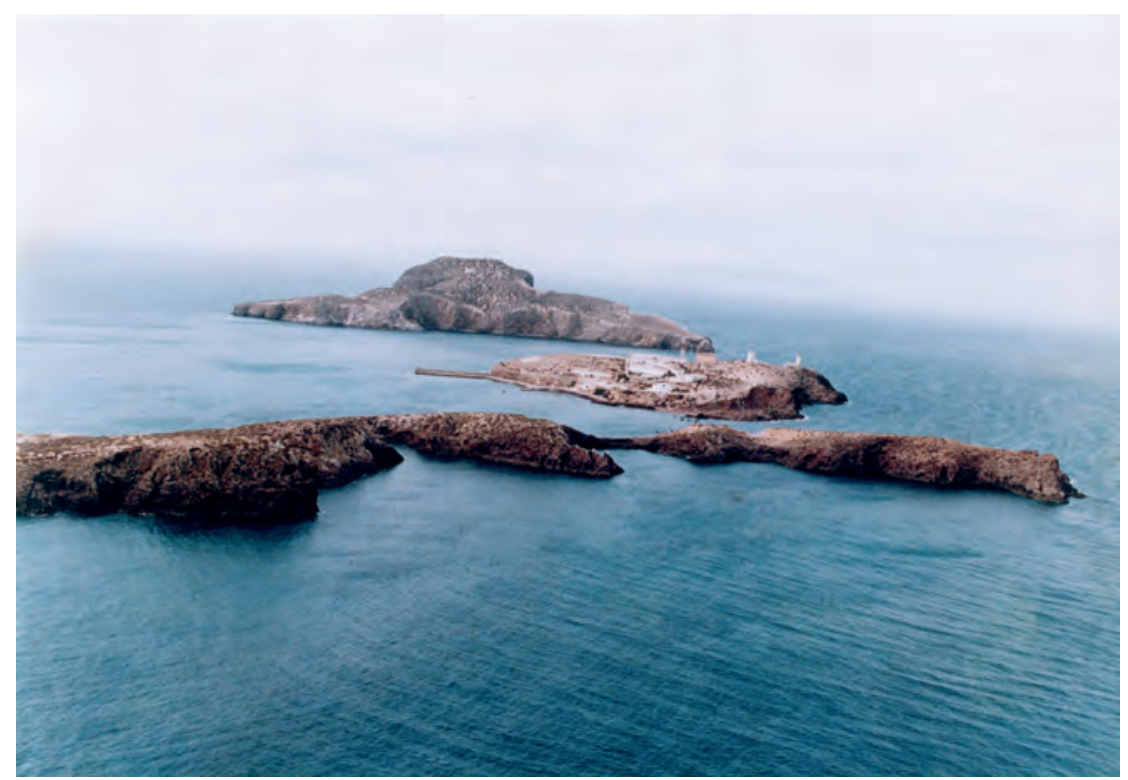

Vista del archipiélago de las Chafarinas.

2. Rompeolas en la punta norte de la isla del Congreso, con una longitud de 1.200 pies (365.76 m.), mediante una escollera que uniría la Laja con la isla, para impedir la entrada en el fondeadero de los temporales del noroeste, que resbalarían "a lo largo de Isabel II, desapareciendo sus desastrosos efectos". Para la construcción de este rompeolas proponían bloques de hormigón hidráulico, desechándose una vez más, y por las mismas razones, la escollera a piedra perdida. El plazo de ejecución de esta parte del proyecto, estimado en unos cinco años y los mismos operarios, pecaba de optimista porque su ejecución exigía teminar primero el cierre del freo chico, presentaba grandes retos logísticos, sobre todo 
de suministros, tenía mayores costes y la tecnología de la época estaba aún muy poco desarrollada.



Proyecto para puerto de José Ma Aparici, 1859. Servicio Geográfico del Ejército.

El presupuesto para el total de la obra ascendía a 6.730.000 eales ${ }^{3}$, de los cuales 3.000.000 eran para el cierre del freo chico y el resto para el rompeolas. Con estas obras, más el malecón situado en la parte SE de Isabel II, se conseguía un puerto resguardado y capaz para recibir buques de gran tonelaje, protegidos de los vientos del NE y SE, por hallar se en el saco for mado por el cabo Tres Forcas y el de Pégalo, fuera del alcance de los vientos del NO que entrarían directamente a través del "freo grande", una vez ejecutado el rompeolas.

3 La peseta fue moneda de curso legal en España a partir de su aprobación el 19 de octubre de 1868 y venía a equivaler unos cuatro reales. 


\section{b) La declaración de puerto franco.}

Por ley de 18 de mayo de 1863 se declararon puertos francos las plazas de Ceuta, Melilla y Chafarinas. Ninguna contaba con obras que permitiera afirmar que tenían algo parecido a un puerto y sin embargo, a efectos fiscales, tenían la consideración de puertos francos. Parece un contrasentido, pero en la práctica la declaración de puerto franco y las iniciativas económicas que se desarrollaron al amparo de tan benigno régimen aduanero contribuyeron a que Melilla, Ceuta e indirectamente Chafarinas, pasados los años, contaran con un verdadero puerto.

\section{c) Obras portuarias ejecutadas.}

El proyecto de Aparici, después de infinidad de vueltas por despac hos y ministerios, fue retomado por el Ministerio de Defensa a principios de los años noventa y contó con dotación pr esupuestaria. Así, en 1903 se señalaba en un artículo $^{4}$ que "...verdad es que el General Azcárraga cuando fue Ministro de la Guera", hace algún tiempo, incluyó en el presupuesto de su Ministerio 275.000 pesetas, cantidad que se consideró necesaria para unir por medio de una escollen, las islas del Rey y de Isabel II de las Chafarinas, que distan entre sí solamente un cable, y con cuya obra tan sencilla convertiría aquel lugar en uno de los mejor es puertos del Mediterráneo. Según se me ha dicho por persona muy autor izada en el Minister io de la Guer ra creían ya concluida la escollera, cuando se enter aron que se había a gotado el presupuesto sin haber hecho casi nada, lo que ha dado lugar a sabrosos comentarios tanto en Chafarinas como en Melilla"

Por otra parte, en el año 1891, en la propuesta de inversión ${ }^{6}$ para Chafarinas en el período 1894-1895, se menciona que existían aprobadas, para invertir durante el año, 50.000 pesetas en el ciere del freo chico, que posteriormente se redujeron a 45.190 pesetas por Real Orden de 11 de septiembre último.

En 1894 se denunciaba públicamente ${ }^{7}$ la suma de proyectos y trabajos olvidados en el Ministerio de la Guerra y cómo estos planes, que fueron sometidos para su estudio nuevamente a los ingenieros militares Lombera y Aparici, dieron

4 Vida Marítima, Año II, num. 51, 30 de mayo de 1903, “La alianza con Inglaterra”, página 287.

5 Marcelo Azcárraga y Palmero (1832-1915) fue ministro de la Guerra en varios gabinetes de Cánovas (julio de 1890, diciembre de 1892, marzo de 1895 y agosto de 1897).

6 Signatura 1561-8. Propuesta de inversión para Chafarinas en el período 1894-1895. Archivo Intermedio Militar de Melilla. COMGEMEL.

7 LA ÉPOCA, febrero de 1894, "El Puerto de Chafarinas". 
lugar a una de las pocas obras que allí se habían iniciado, "sin que al cabo de treinta y cinco años la obra total, que ofrece tantas ventajas, así a la mar ina militar como a la mercante, se haya emprendido...”. A estas mismas obras se refiere el historiador Gabriel de Morales ${ }^{8}$, cuando escribe que "el puerto de Chafarinas comenzó a construirse por el Ministerio de la Guerra pocos años después de 1893;pero con consignaciones insignificantes de 20 o 25.000 pesetas anuales, sucedió lo que era de prever, que la obra hecha con la consignación de un año se la llevaba el mar en un día mediano de temporal”. Y también, Francisco Carcaño Más ${ }^{9}$, cuando afirma que en su tiempo las islas estuvier on unidas "por un dique que comenzaron los ing enieros militares y continuaron los civiles hasta que un horroroso Levante los destrozó, y si bien la rotura no perjudica el fondeadero, interrumpe la comunicación por tier ra. Se tomaba tier ra en un muellecito de hor migón muy deteriorado, sobre todo desde que se abandonó para construir el puerto".

Según Manuel Becerra ${ }^{10}$ con sujeción al proyecto de Aparici y Lombera se ejecutaron, a finales del siglo XIX y principios del XX, por parte del Cuerpo de Ingenieros, las obras de unión de las islas del Rey y de Isabel II, que nunca llegaron a ter minarse pues en 1904 apenas quedaban de las mismas "en el Canal y fondeadero, bajos formados por escollera menuda en general con la que se pretendió construir el dique o rompeolas". Aunque Becerra no llegó a disponer de un ejemplar del proyecto en base al cual se ejecutarn estas obras, a la vista de las ejecutadas ceía que "el dique se proyectaría con escollera y acaso la falta de medios, de trabajos preliminares, de no haberse tenido todo el cuidado necesario en la clasificación de la escollen y en su inmersión, ser aquella de b loques pequeños en su ma yor parte, y por último al haberse fijado el eje del dique, en la cresta que forma el fondo del Canal, sin dejar una ancha berma, han determinado en el primer temporal la destrucción de la obra hecha”. Becerra se equivocaba, pues, como hemos visto, el muelle se proyectó con bloques artificiales de hormigón y no con escollera naural, que era expresamente rechazada por los autores del proyecto; aunque lo más probable es que en la fase de ejecución, ante la falta de materias primas (arena, cales hidráulicas, cemento, etc.) y

8 MORALES MENDIGUTÍA, Gabriel de (1909). Datos para la historia de Melilla. El Telegrama del Rif.

9 CARCAÑO MAS, Francisco (1921). Melilla Rifeñerías. Las Plazas Menor es de África. Excmo. Ayuntamiento de Melilla. La Biblioteca de Melilla, reedición de 1981.

10 Anteproyecto de mejora del Puerto de Chafarinas. Archivo de la Autoridad Portuaria. Sección de Proyecto. Proyecto ${ }^{\circ} 4$. 
medios técnicos (grúa, etc.) se optara por cambiar los sillar es artificiales por la escollera perdida, tan abundante en las islas. Estas obras, que fueron ejecutadas con los penados, tenían como toda maquinaria una grúa de mano de escasa potencia que permitía depositar la escollera en el mar, que previamente había sido arrancada a golpes de barrenos y transportada en vagonetas, empujadas por los propios penados, hasta la playa.

En definitiva, cuarenta y cinco años después del pr oyecto de Aparici, invertidas 400.000 pesetas $^{11}$ de la época en su ejecución,con métodos tan inocentes y medios tan ridículos, sólo quedaban los restos de unas obras esparcidos en el fondo del mar y una retahíla de estudios y propuestas, envueltos en los deseos, esfuerzos y frustraciones de todos los que habían defendido la idea de un puerto para Chafarinas.

\section{d) El muelle de embarque.}

En la Memoria de Aparici de 1858 se proponía, además, la construcción de un pequeño muelle, protegido de los vientos del noreste, para la descarga de efectos y materiales empleados en las obras que en ese momento estaban en ejecución en las islas, su abastecimiento ordinario y, sobre todo, el de las obras previstas para el futuro.

Unos meses más tarde, en mayo del mismo año, Juan Manuel Lombera firmaba un proyecto de muelle para la isla de Isabel II, por el sistema de bloques de betón, a partir del proyecto redactado por Aparici. En 1859 este pr oyecto estaba aprobado por la superioridad y, aunque no tenemos datos precisos sobre su construcción, sabemos que en 1860 aún no se había construido y todo parece indicar, debido a los temporales y a la escasez de pesupuestos, materiales y operarios, que su finalización costó bastantes años hasta el punto que en 1870 aún se trabajaba en su construcción ${ }^{12}$ o mejor dicho en su reconstrucción.

Veintidós años después, en 1881, ante el estado de deterioro, se tuvo que redactar un proyecto de muelle provisional de madera, pues el mal estado del muelle permanente apenas permitía el atraque y el desembarque. En 1883, en noticia publicada en El Liberal, se decía que el muelle se encontraba "completamen-

\footnotetext{
11 "Los puertos españoles norteafricanos", Vida Marítima, num. 274, 10 de agosto de 1909.

12 No obstante, ya en 1869 el muelle era operativo.
} 
te desbaratado por los embates del mar, lo que dificulta extraordinariamente las operaciones de carga, que se hacen con gran peligro".

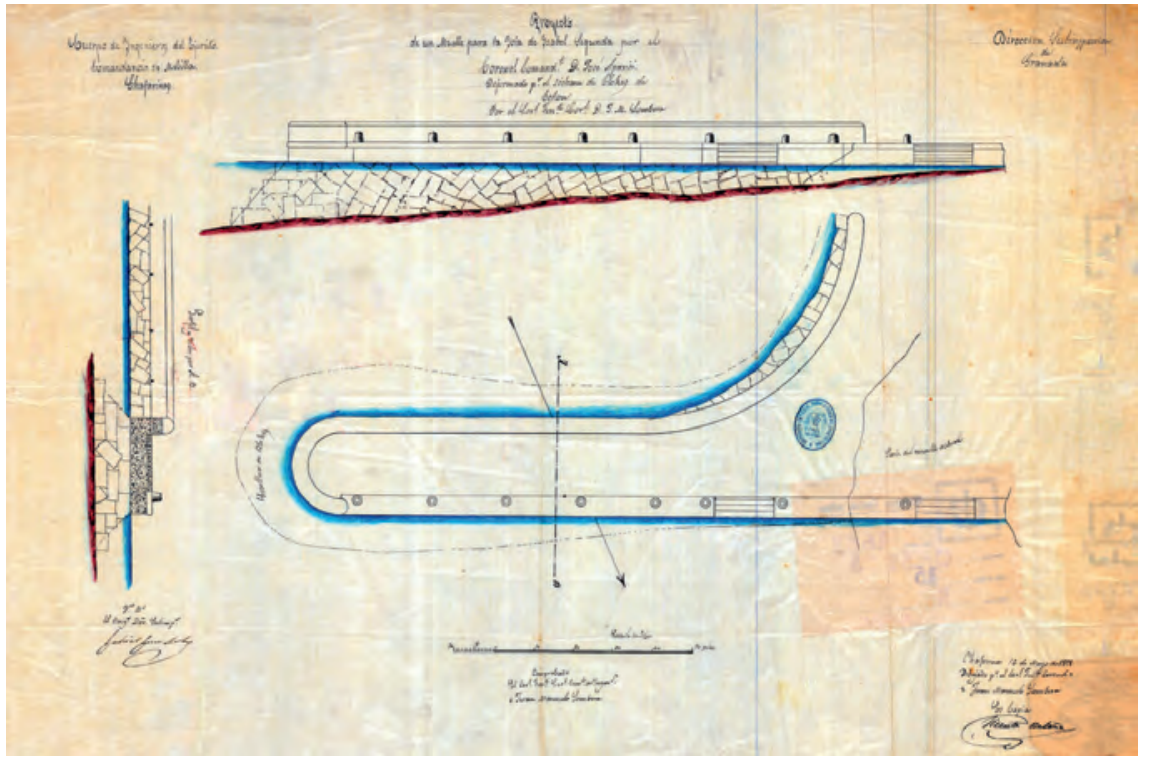

Plano extraído del proyecto de 1858 para la construcción de un muelle para la isla de Isabel II de D. José $M^{a}$ Aparici y reformado por D. Juan Manuel Lombera. Cartoteca Archivo Militar General de Madrid.

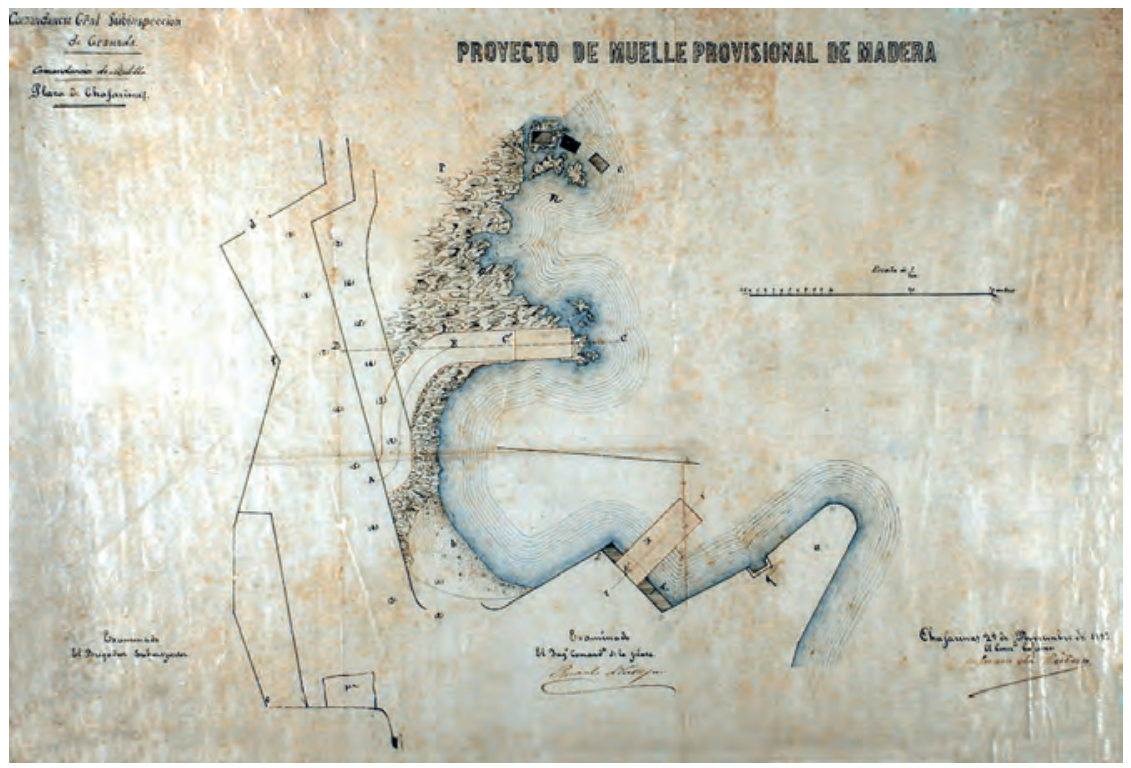

Proyecto de muelle provisional de madera para la isla de Isabel II, 1881. AIMM. 
La lucha de las autoridades militares para lograr que el Gobierno librara presupuestos para atender las necesidades de Chafarinas eran constantes, reiteradas e incluso desesperadas, hasta el punto que muchas de sus quejas trascendían los canales oficiales y se proyectaban en los medios de comunicación, que a través de las crónicas de sus cor responsales dibujaban un panorama desolador sobre su estado de abandono, desidia administrativa y mal gobierno ${ }^{13}$.

Deberían de pasar años para que las obras de reparación fueran aprobadas e incorporadas en el presupuesto de inversiones ${ }^{14}$ de 1895 y ejecutadas en 1896 , por importe total de 4.690 pesetas, pues la importancia de este muelle era fundamental para el abastecimiento de las islas A falta de instalaciones artificiales de atraque, los barcos fondeaban en el puerto natural y desde ahí todo el desembarco se realizaba a remo, con los botes de la Compañía de Mar que lle vaban a personas y mercancías desde el buque al muelle y viceversa. Las obras eran urgentes y necesarias pues el mal estado del muelle ponía en peligro hasta el abastecimiento de agua a las islas.

Esta lucha constante entre necesidad y pocos presupuestos, entre súplicas de las autoridades locales y silencio guber namental, terminaría por agotar los proyectos militares que, abandonados durantes años, retomados con tibieza y faltos de presupuestos, cederían ante las inclemencias meteorológicas y abrirían el camino a los proyectos civiles, una vez entrado el siglo XX, al amparo de la Ley que declaraba a Melilla como puerto de interés general (1902) y de la constitución de la Junta de Obras del Puerto de Melilla y Chafarinas.

\section{e) La señales marítimas.}

Una vez más sería José María Aparici el primero en redactar un proyecto de Vigía en la isla de Isabel II, constituida por una torre de planta cuadrada, dos metros de altura y rematada con una luz blanca (visible en unas 25 millas) de la que no a visaron a nadie y que fue oficialmente ad vertida por un anuncio del Depósito Hidrográfico de cartas y planos de París ${ }^{15}$. En $1887^{16}$ se escribía que

\footnotetext{
14 Signatura: 1516/17. Propuesta de inversión aprobada por la Real Orden de 26 de julio de 1895 . Archivo Intermedio Militar de Melilla. COMGEMEL.

15 SÁNCHEZ TERRY, Miguel Ángel (1993).Faros españoles del Mediterráneo. Servicio de Publicaciones del Ministerio de Fomento. Madrid.

16 Revista de Geografía Comercial, España Mauritana, 30 de abril de 1887, núm. 36, página 271.
} 
“... un puerto como este, tiene por todo faro una mala farola de petróleo, montada en el fuerte N. de la isla de Isabel II"a pesar de que desde la Comisión de Fros, con fecha 15 de mayo de 1859 se había acordado establecer un faro de $3^{\circ}$ orden con destellos, en el sitio denominado Punta España de la isla de Isabel II.

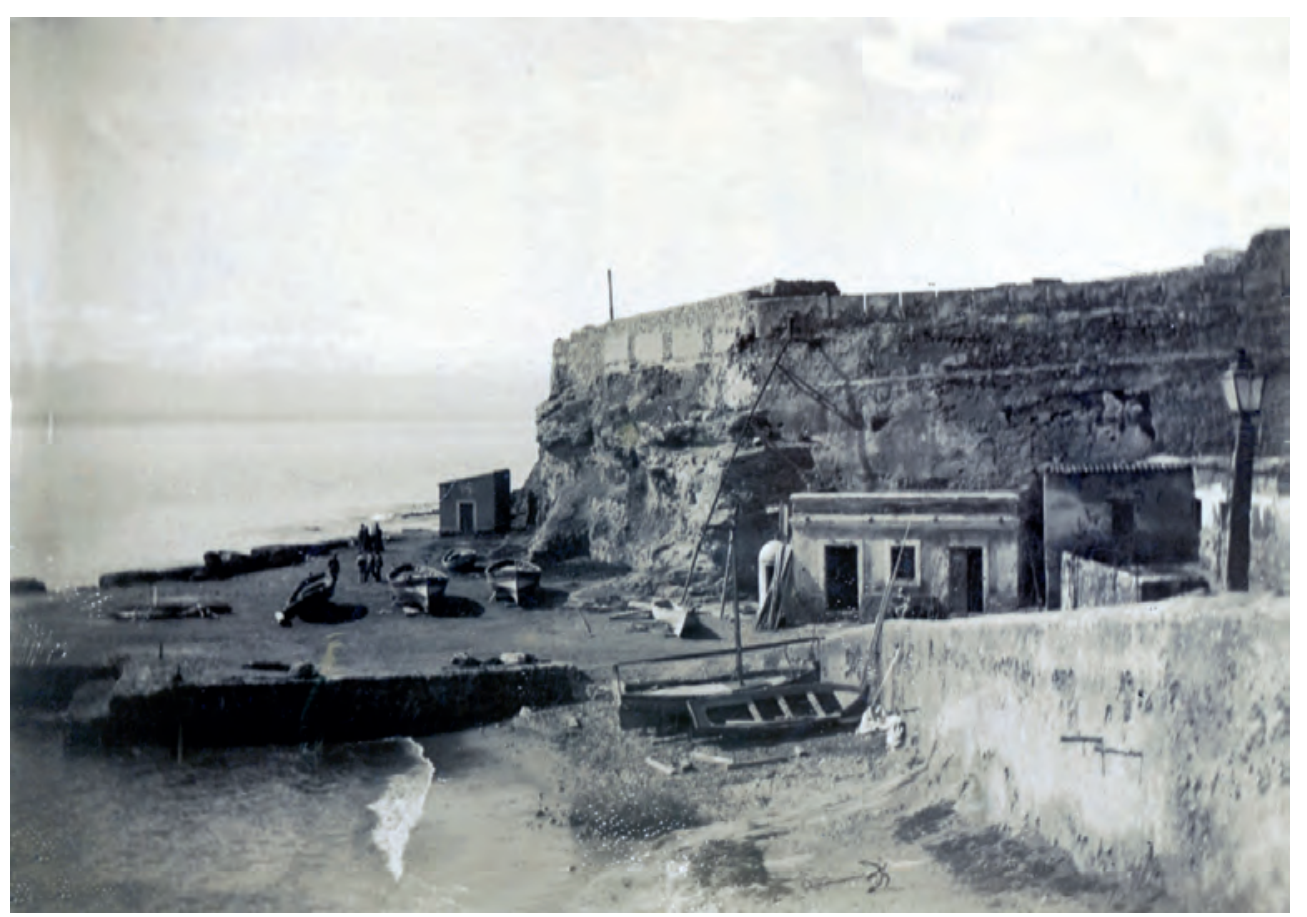

El puerto en una fotografía de finales del siglo XIX. FCOML.

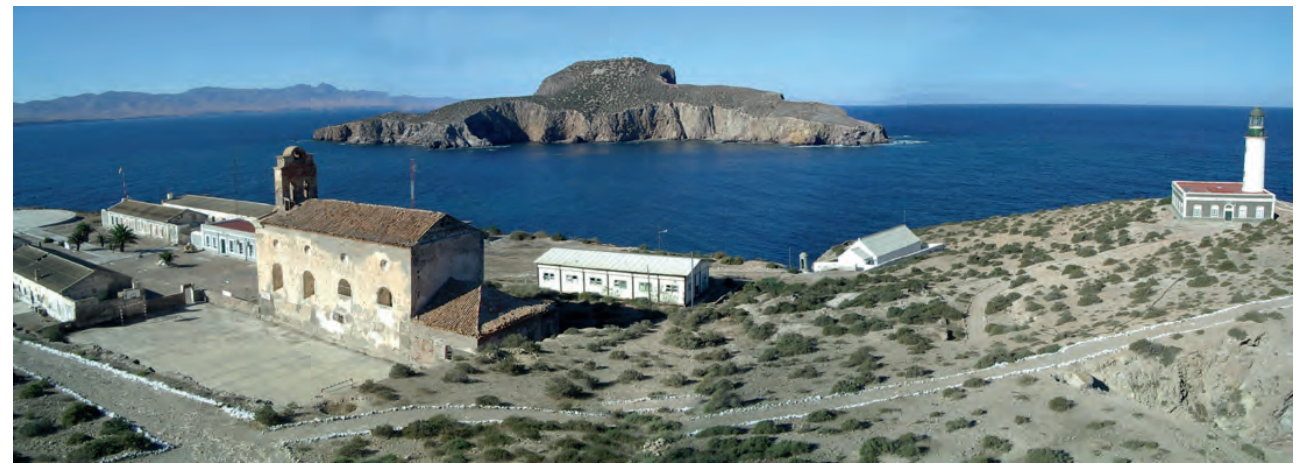

Vista general del extremo noroeste de la isla de Isabel II orientado a la del Congreso, al fondo. Fotografía Carlos del Campo. 
En efecto, la Comisión de Faros en mayo de 1859 proponía la señalización marítima necesaria para los presidios de África. Esta propuesta, aprobada por los Ministerios de Guerra y Marina con pequeñas observaciones, no alcanzó el grado de proyecto hasta el año 1885 en el que el Ingenier o Jefe de la Provincia de Cádiz elevó a la superioridad los proyectos de los cuatro faros ${ }^{17}$.

Tras diversos informes una Comisión Mixta, compuesta por el comandante de Ingenieros de la Plaza de Melilla y un ingenier o de caminos, redactó las bases para la redacción de los proyectos ${ }^{18}$. En estas bases se cambiaba el emplazamiento del faro de Chafarinas (antes previsto en la isla del Congreso) a la isla del Isabel II en el lugar denominado Punta España, un pequeño saliente en la par te septentrional de la isla a unos 32,58 metros sobre el nivel del mar, al oeste de la torre del vigía y al norte del polvorín.

En 1894 se redactó el "Proyecto de cuatro Faros para las posesiones Españolas de la costa Norte de África” por el ingeniero José Enrique Rosende ${ }^{19}$, que contemplaba un faro de $3^{\circ}$ Orden, con una altura de 18,50 sobre el terreno y una luz fija blanca variada por destellos cada 30", y 18 millas de alcance. La vieja luz de la torre del vigía estaba ligeramente más alta que la luz del nueo faro, a pesar de lo cual el autor del proyecto no consideró necesario darle más altura, pues según el proyecto de fortificaciones del Ministerio de la Guerra estaba previsto demoler la torre del vigía (cosa que no se hizo), de modo que en el futur o no existiera ninguna edificación que ocultara la luz del faro.

La ubicación del faro en la isla de Isabel II, su altura y el perfil de la isla del Congreso, provocaba que la luz quedara oculta en un sector de $36^{\circ} 30^{\prime}$ Para salvar este obstáculo hubiera sido necesario elevar 18 metros más la torre del faro, lo que le hubiera dado unas dimensiones extraordinarias y, además, con esa altura apenas se disminuía el sector oscur o y se incr ementaba considerablemente el coste del proyecto. Según el proyecto este inconveniente no afectaba a los buques que navegaran en dirección al Estrecho de Gibraltar o hacia el Canal de Suez, por estar el faro situado en la par te más avanzada de las islas y por la der rota que tenían que seguir. El pr oblema era diferente para las embarcaciones que na vegaban por la

17 Estos proyectos fueron devueltos en enero de 1886 a fin de que se introdujeran las modificaciones propuestas por la Junta Consultiva que se referían, por un lado, al Orden al que debía pertenecer cada faro y a la apariencia de sus luces y, por otro, las características de los edificios.

18 Aprobadas por la Dirección General de Obras Públicas el 27 de julio de 1889.

19 José Enrique Rosende Martínez, fue desde 1904 Director del Puerto de Ceuta. 
costa, las cuales al acercarse a las islas, debido a la derrota que tenían que seguir, se adentraban en el sector oscur o. Para resolver estos inconvenientes se sugirió la instalación de una luz de último orden en el extremo sur de la isla del Congreso ${ }^{20}$.

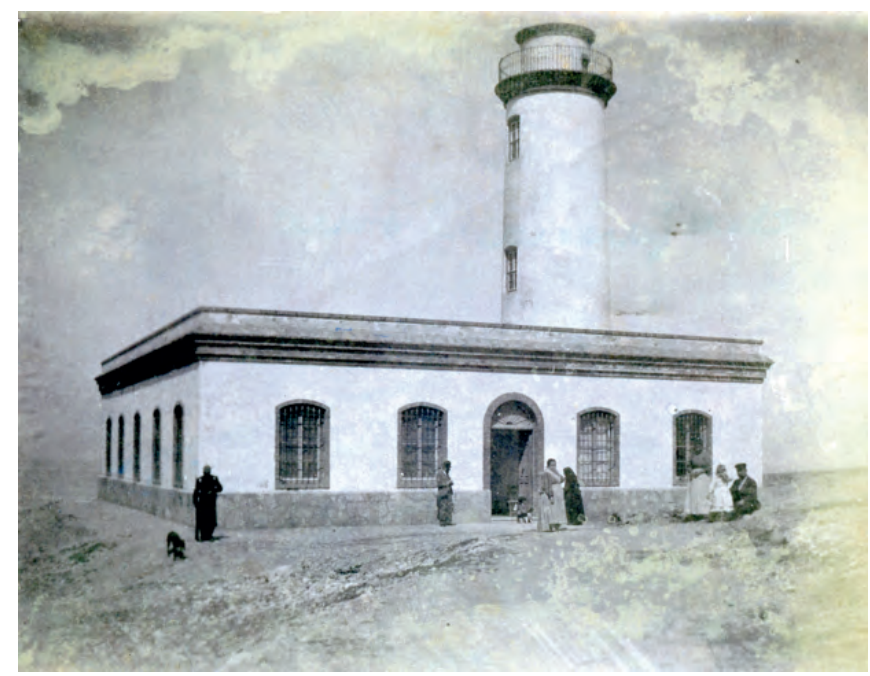

El faro de las Chafarinas recién construido y situado al norte de la isla de Isabel II a finales del siglo XIX. FCOML.

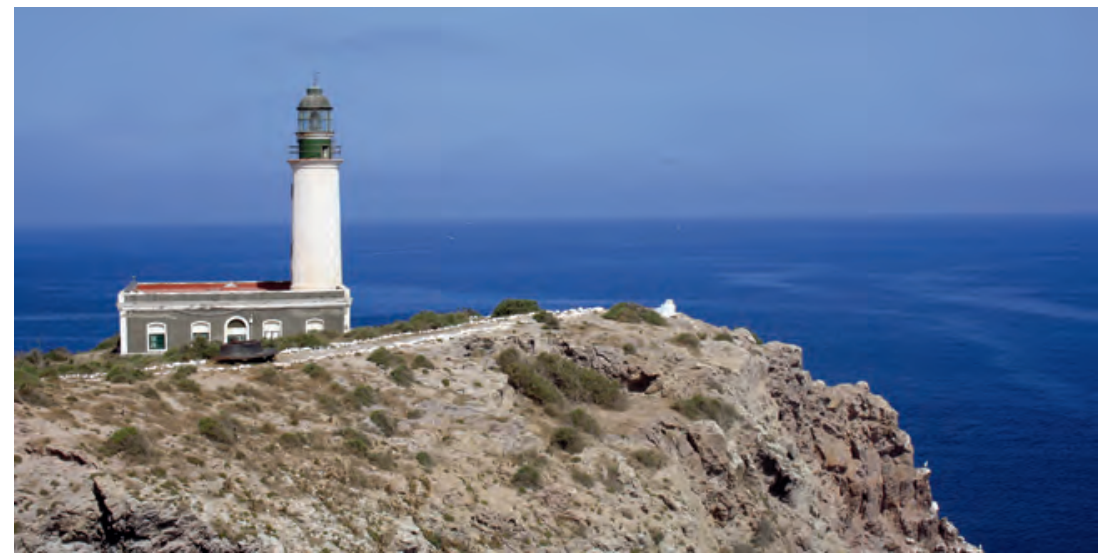

El faro situado en la isla de Isabel II, en su extremo noroeste, en la actualidad. Fuente: Francisco Álvarez.

${ }^{20}$ Expediente número 25115/7. Proyectos de cuatro faros para las posesiones españolas de la Costa Norte de África: Melilla, Chafarinas, Peñón de Alhucemas y PeñónVélez de la Gomera. José E. Rosende, ingeniero. Archivo Histórico Provincial de Málaga. Consejería de Cultura. Junta de Andalucía. 


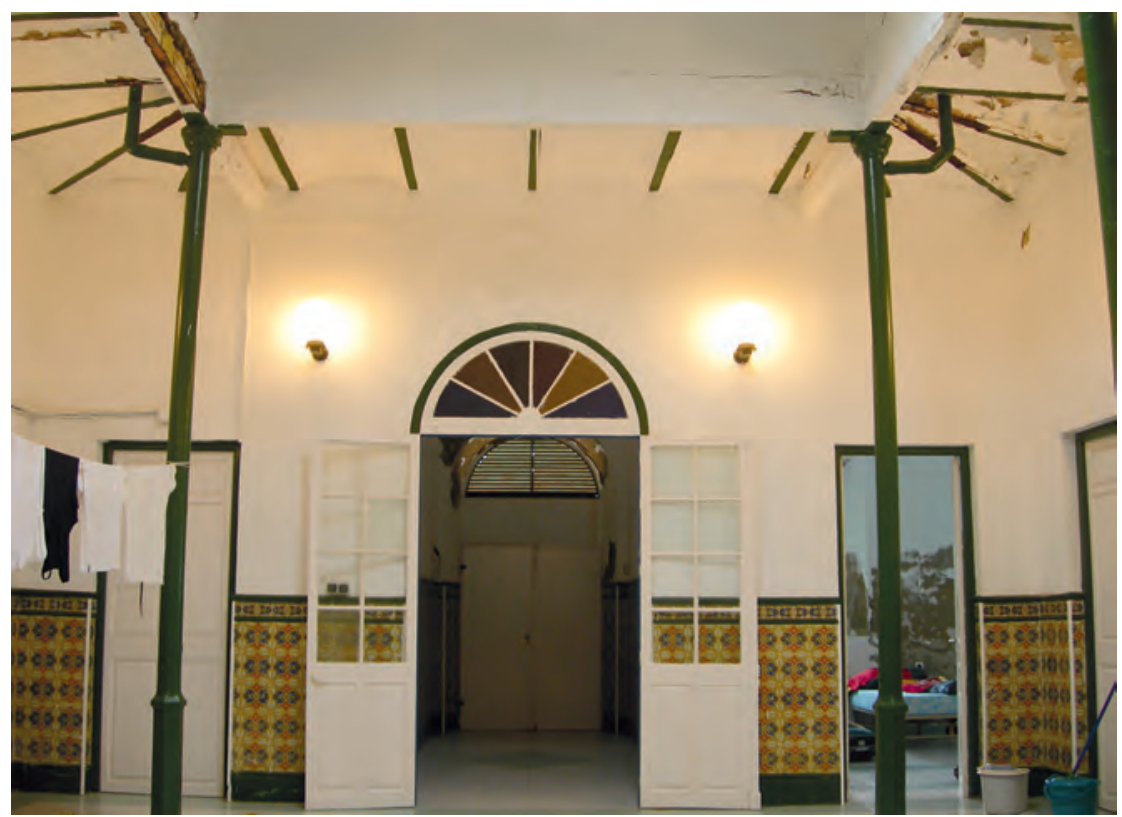

Interior del faro antes de la última restauración. Alrededor de la sala principal se distribuyen todas las habitaciones.

El proyecto de faro proponía un edificio de planta rectangular, casi cuadrada, de 17 X 19 metros, con una superficie de 323 metros cuadrados y un patio interior de 9 x 7 metr os. Esta edificación contenía la tor re circular del far o, adosada a la fachada norte y casas para dos torreros, retretes, despachos, almacenes, etc., todo ello distribuido a partir del patio interior. Dada la falta de agua en Chafarinas el proyecto integraba en el edificio un singular aljibe de 36,30 metos cúbicos emplazado en el centro del patio, con fondo de hormigón y paredes de ladrillos enlucidos con cemento hidráulico, que recogía el agua recibida a través de las cubiertas del edificio.

Las obras con un presupuesto de contrata de 51.507,22 pesetas fueron adjudicadas al único gran contratista que en esos momentos trabajaba en Melilla, Francisco Orozco y Granados, que dentro del plazo previsto terminaría la obra civil, firmándose el Acta de Recepción Provisional el 28 de agosto de 1896 y el Acta de Recepción Definitiva con fecha de 17 de septiembr e de $1897^{21}$. Según Miguel

21 Expediente 27045. Faro de Chafarinas, Actas de las obras del Edificio, 1896-1897. Archivo Histórico Provincial de Málaga. Consejería de Cultura. Junta de Andalucía 
Ángel SánchezTerry ${ }^{22}$ el faro fue inaugurado en 1899 y tenía un aparđo de $3^{\circ}$ Orden gran modelo, luz fija blanca variada por destellos cada 30 3, 18 millas de alcance en tiempo ordinario y estaba atendido por dos torreros. Por su parte, Gabriel de Morales, dice que el faro se inauguró el 1 de agosto de 1901,aportando datos técnicos del mismo que difieren ligeramente de los del proyecto ${ }^{23}$. En cuanto a las características técnicas de la luz, seguimos al citado autor Miguel Ángel Sánchez Terry ${ }^{24}$.

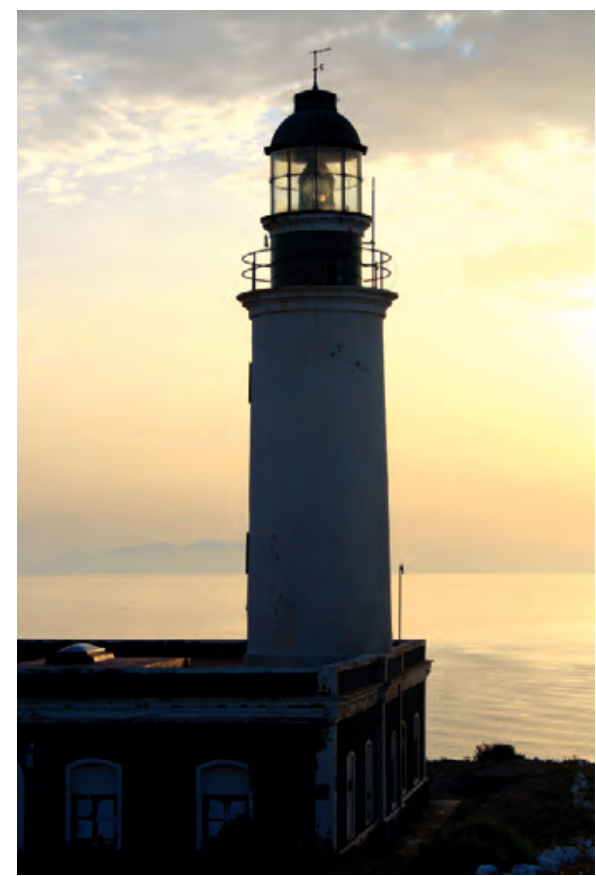

Faro de Isabel II antes de las últimas reformas. Fuente: Francisco Álvarez.

22 Obra citada.

23 Posteriormente hubo más obras en este edificio En 1918, por Real Orden de 7 de octube, se aprobó un proyecto de ampliación de la cimentación del fro para asegurar la estabilidad del edificioY en 1919 se aprobó el proyecto complementario del de ampliación de los cimientos, redactado por el ingeniero Manuel Delgado y Delgado, pues el edificio presentaba grietas en sus cubiertas producidas por la continua infiltración de las aguas, que habían oxidado y descompuesto las viguetas metálicas. Con este nuevo proyecto se acometió una nueva cubierta, pues la antigua amenazaba ruina, con un presupuesto de contrata de 23.752,65 pesetas. A lo largo de los años, se ha acometido diversos proyectos destinados a reformar y rehabilitar el edificio, especialmente desde que el mismo quedó inhabitado lo que aceleró su deterioro. Su última reforma se remonta al año 2010 en el que se lleva a cabo el proyecto de "Mejora del Faro de Chafarinas por un importe de 274.977,05 euros.

24 Según Miguel Ángel Sánchez Terry, en la obra citada, como alumbrado del faro se utilizó un sistema de vapor de petróleo por incandescencia Chance 85, automatizándose, en 1927, con una instala- 
Como obras complementarias del faro principal, en 1915 se instaló en el morro del dique del oeste una luz de posición, encarnada, para prevenir a los navegantes y en enero de 1916 la Comandancia Militar comenzó la constracción de un pequeño torreón para la colocación de una luz en la punta sur de la isla del Congreso, que fue encendida el 20 de julio de 1917, quedando a disposición de la Jefatura de Obras Públicas de Málaga.
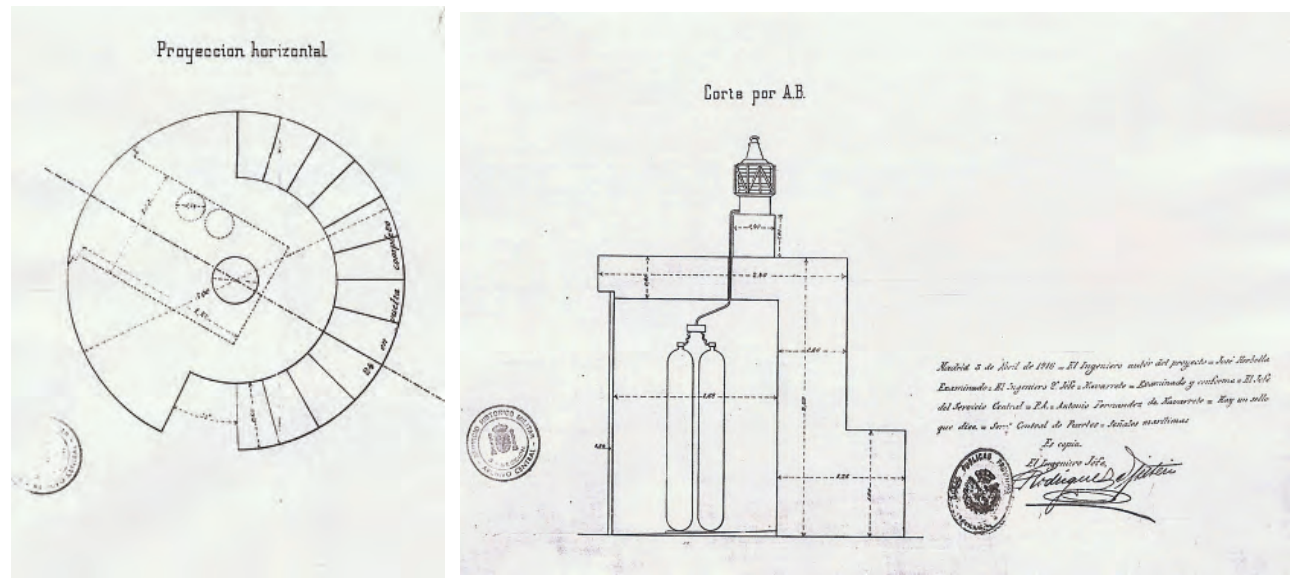

Proyecto para la instalación de una luz en la punta sur de la isla del Congreso por José Herbella, 1916. Archivo General Militar de Madrid.

En 1994 se adscribieron ${ }^{25}$ a la Autoridad Portuaria de Melilla las instalaciones de iluminación de costas y señalización marítima de Melilla, Chafarinas, Alhucemas y Peñón de Vélez. Hoy día, junto al antiguo faro, las señales marítimas de las islas se complementan con la baliza 73.110, en el puerto de Isabel II, emplazada en el extremo del muelle "El Titán", con un plano focal a 9 metr os sobre el nivel medio del mar y de 7 sobre el terreno, y la baliza 73.120, empla-

ción de acetileno por incandescencia Dalen, con quemador para 50 1, válvula solar y cuatro acumuladores AK-25 que darían la característica de un destello thanco cada 43 , con un alcance en tiempo ordinario de 20 millas. Y en 1984, con la electrificación del faro, aprovechando las linternas y ópticas disponibles, se instalaron lámparas de 50w/24v con destelladores, cambiadores, reguladores, contadores, paneles y demás aparatos junto a las correspondientes baterías. La característica de Chafarinas quedó en destellos aislados con un grupo de baterías de $514 \mathrm{a} / \mathrm{h}$ de capacidad y paneles de 22,79 ah/d.

25 Mediante Orden de 28 deAbril de 1994 del Ministerio de Obras Públicas y Transportes, BOE de 6 de mayo. 
zada en la zona sur de la isla del Cong reso, con un plano focal a 36 metr os del nivel medio del mar y a 3 metros sobre el terreno.
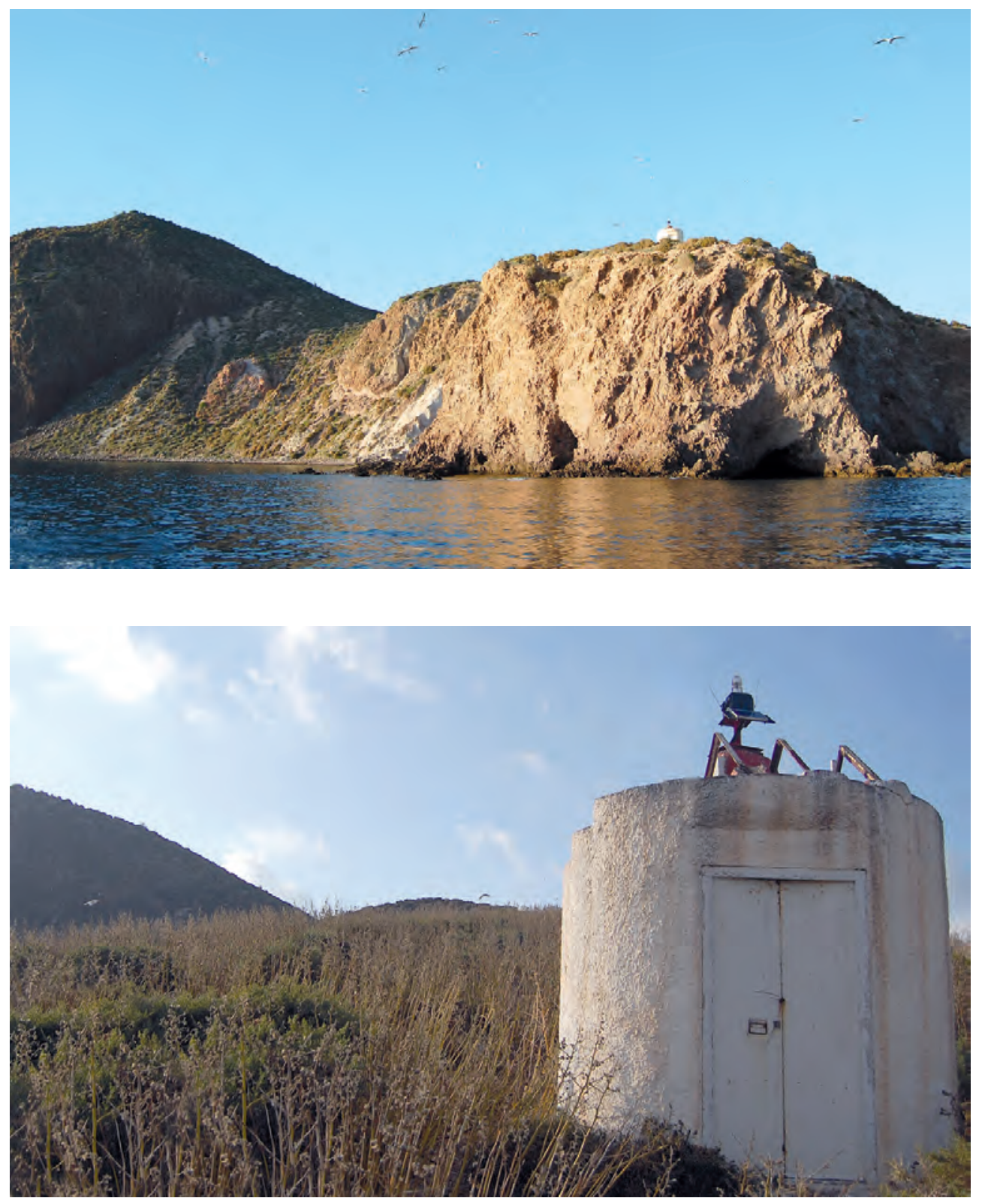

Baliza luminosa en el brazo sur de la isla del Congreso. Fotos: Javier Guallart. 

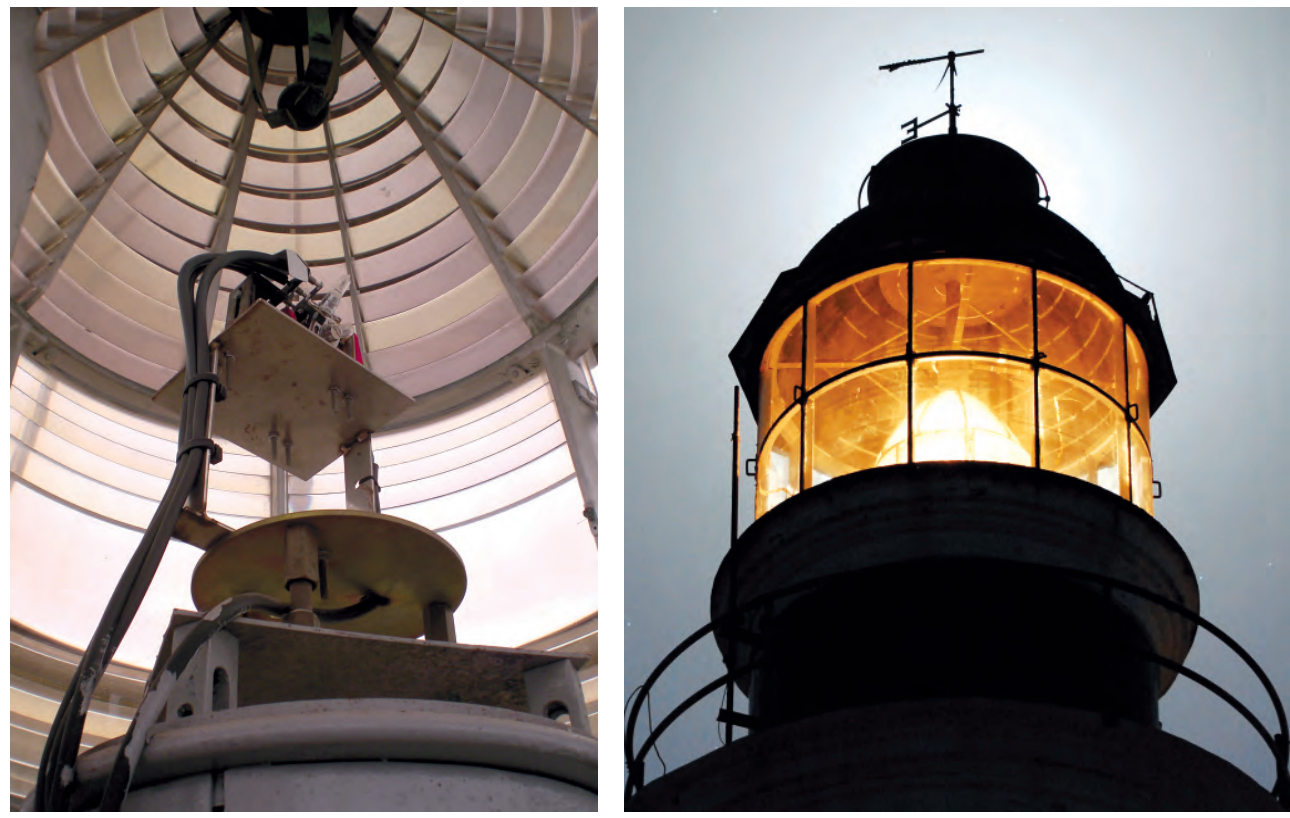

Interior y exterior de la linterna del faro de Chafarinas en la actualidad. Foto: José María Peñuela.

\section{Proyectos civiles para el puerto de Chafarinas}

\section{a) Los proyectos.}

Como no podía ser de otra forma, los proyectos civiles de un puerto para Chafarinas se plantearon en el ámbito de la Junta de Obras del Puerto ${ }^{26}$ y tuvieron como referencia inmediata los proyectos militares redactados anteriormente y el "Plan de Puer tos y Faros en la costa de Áfr ica" del ingeniero Francisco Lafarga. Este autor pr oponía que el puer to de Chafarinas fuera declarado de interés general, considerado como de refugio, y que el Minister io de Fomento estudiara el proyecto definitivo de puer to a par tir del estudio hec ho por los ingenieros militares, asumiendo su conservación y explotación ${ }^{27}$.

26 Creada por Real Orden 18 de diciembre de 1902.

27 LAFARGA CABIEDES, Francisco (1894). "Plazas españolas en África: plan de puertos, faros y valizas”. Revista de Obras Públicas, Núm. 20. Madrid. 
Parte del plan se haría efectiv o a principios del siglo pasado, aunque sin la declaración de puer to de interés general. Para ello, Manuel Becerra Fernández, poco después de ser nombrado Director de la Junta del Puerto ${ }^{28}$, recibió la orden de trasladarse a Chafarinas para estudiar las posibilidades de su puer to y redactar un proyecto ${ }^{29}$. El 8 de septiembr e de 1904, Becerra firmaba el "Anteproyecto de mejora del Puerto de Chafarinas", que tras diversas correcciones se convertiría en la piedra angular sobre la que se redactarían todos los proyectos posteriores. El anteproyecto se convirtió primero en "Proyecto de mejora del Puerto de Chafarinas (1904)", más tarde en el "Proyecto definitivo de mejora del Puerto de Chafarinas (1905) 31" y final-

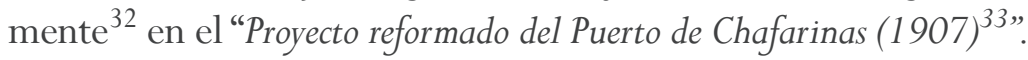

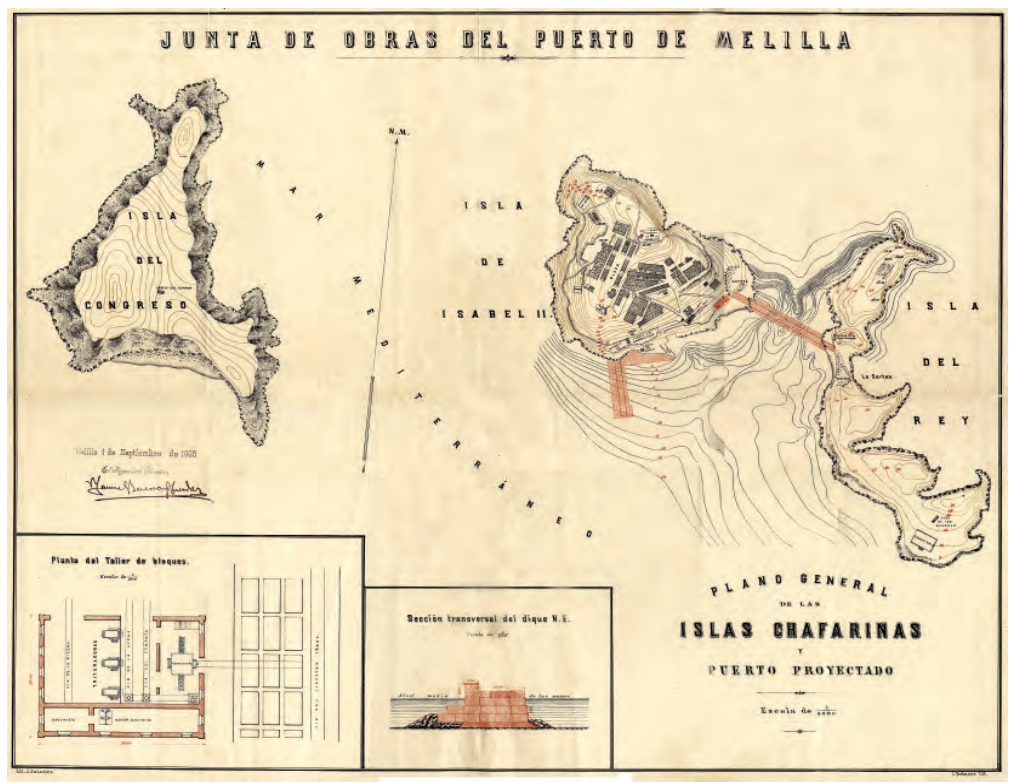

Plano General de las islas Chafarinas y puerto proyectado. Autoridad Portuaria de Melilla.

28 Por Real Orden de 1 de marzo de 1904, Manuel Becerra fue nombrado Director Facultativo de las obras del puerto de Melilla y Chafarinas y tomó posesión el 28 de dicho mes.

29 Viaje que se produjo el 23 de junio de 1904, a bordo del v apor "Sevilla", acompañado de personal facultativo y subalterno.

30 Archivo de la Autoridad Portuaria. Sección de Proyecto. Proyecto n ${ }^{\circ} 6$.

31 Archivo de la Autoridad Portuaria. Sección de Proyecto. Proyecto $n^{\circ} 7$.

32 Este proyecto aún fue objeto de una pequeña r eforma que se incorpora al Proyecto $\mathrm{n}^{\circ} 7 \mathrm{en}$ forma de Memoria adicional, fechada en noviembre de 1908.

33 Archivo de la Autoridad Portuaria. Sección de Proyecto. Proyecto n ${ }^{\circ} 17$. 
Las obras partían de las siguientes consideraciones generales:

Vientos ${ }^{34}$ : Las observaciones realizadas a lo largo de los años, hablaban de que los vientos fuertes en las islas eran los del oeste -siguiendo en fiecuencia los del este, norte y los noreste- y que en el fondeadeo natural formado por las islas de Isabel II y la del Rey se transmitían en épocas de temporales de levante muy poco las marejadas, pues la isla del Rey constituía un dique natural para aquellas. No ocurría lo mismo con los vientos del oeste y nor oeste, dado que la anchura del freo que separaba a la isla del Cong reso con la de Isabel II, por desviación gradual y transmisión lateral, se producían en el fondeadero resacas combinadas que hacía imposible la estancia en el puerto con dichos temporales.

Corrientes: La corriente que penetraba en el Mediter ráneo por el Estrecho de Gibraltar, desviada por la costa y por la orientación de los canales o freos que separaban a las islas,en combinación con las corrientes de marea, originaban hileros de corriente entre el freo de las islas de Isabel II y del Rø tan fuertes que hacía muy difícil mantenerse en fondeadero.

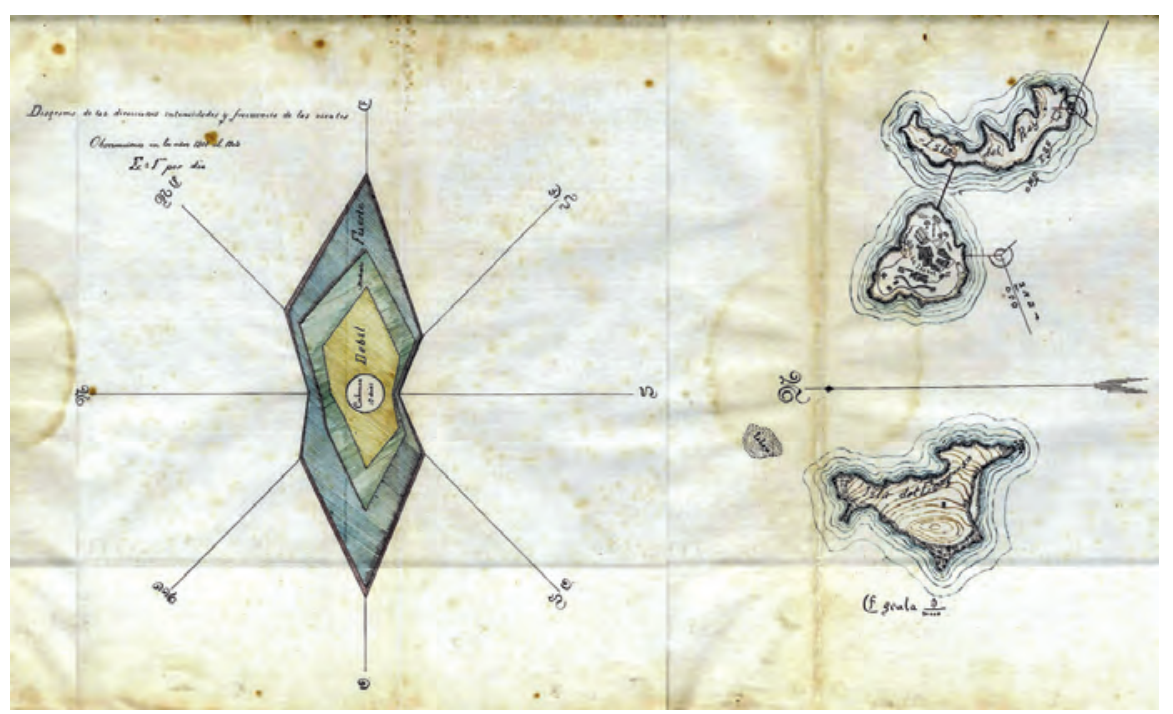

Detalle del plano general del proyecto de mejora del puerto natural de las islas Chafarinas de Manuel Becerra, 1904. Archivo Autoridad Portuaria.

34 Estos nombres indican la procedencia del viento:

- N - Norte - Tramontana - NE - Noreste - Gregario

- SE - Sureste - $\underline{\text { Siroco }}$ - S - Sur - $\underline{\text { Mediodía }}$

- E - Este - Levante

- O - Oeste - $\underline{\text { Poniente } \quad-N O-N o r o e s t e ~-~} \underline{\text { Mistral }}$

- SO - Suroeste - Lebeccio 


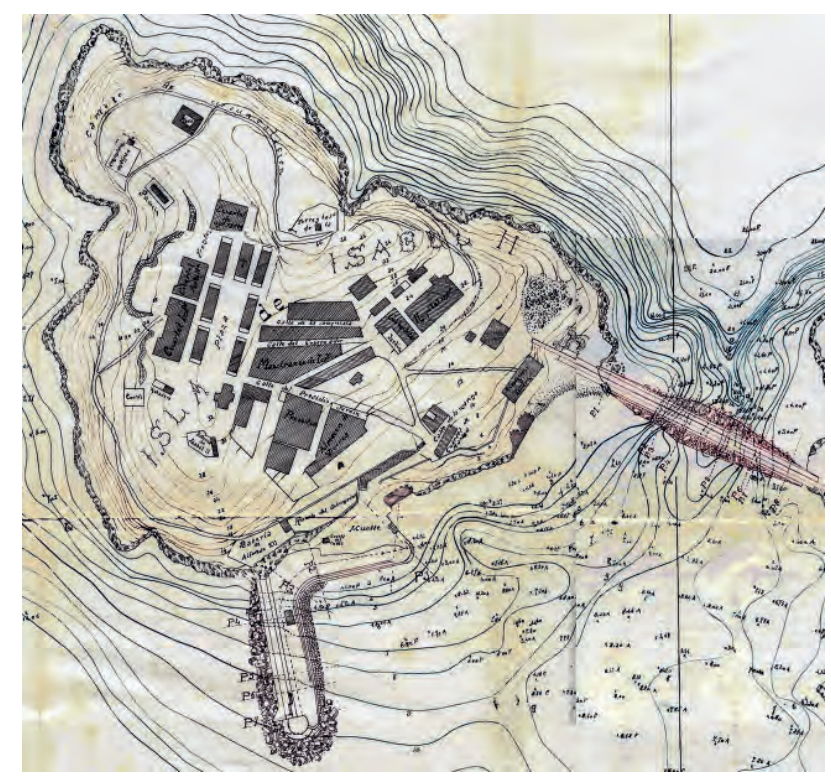

Detalle de la isla de Isabel II donde se proyectan los dos puertos, el dique de unión con la isla del Rey y dique del Oeste. Proyecto definitivo de mejora del puerto de Chafarinas de Manuel Becerra, 1905. Archivo Autoridad Portuaria.

Para Manuel Becerra ${ }^{35}$, su proyecto perseguía obtener un puerto fácil de reconocer desde larga distancia, al abrigo de la mar ejada, de las corrientes, de los vientos, especialmente los tormentosos. Las obras que proponía eran las siguientes:

1. Construcción de un rompeolas y un muelle que cerrara el canal que separaba a la isla de Isabel II de la del Rey.

2. Construcción de un dique de abrigo y muelle paralelo, arrancando del extremo más avanzado al sur de la isla de Isabel II,con el cual defender al fondeadero de las mar ejadas del noroeste y del oeste, con un ár ea abrigada de unas cuatro hectáreas, con calados entre seis y nueve metros. Se esperaba que el fondeadero tuviera capacidad para 16 barcos de dos mil toneladas o veinticinco de mil toneladas.

35 "El puerto de Chafarinas como puerto de refugio principalmente debe cumplir la condición de poderse tomar bien con los NE y E.que son los que producen magores marejadas y la de dar salida expedita con los vientos del $O$, condiciones cumplidas en nuestro pro yecto, por la circunstancia de cubr ir la isla del Cong reso, dique natural a barlovento, a la isla del Rey. Para los temporales de poniente queda abrigado el puerto por el dique del O”. 
3. Construcción de un muelle de costa para el atraque de embarcaciones de tres metros de calado.

4. Relleno de los terrenos ganados al mar comprendidos entre el dique y muelle del oeste y muelle de costa.

5. Instalación de una luz en el morro del dique del oeste.

6. Accesorios para el muelle y boyas para marcar el calado del fondeadero.

7. Otras actuaciones:

- Obras de dragado

- Dos canteras: una en la isla de Isabel II y otra en la del Rey.

- Taller de bloques.

- Edificio para oficinas, almacén de cementos, talleres, central eléctrica, casa del guarda, etc., con una superficie apr oximada de 600 metros cuadrados.

- Vías para el transpor te de escollera, bloques de hor migón, hormigoneras, trituradoras, grúas, etc.

- Embarcadero en la isla del Rey para las gabarras destinadas al vertido de escollera.

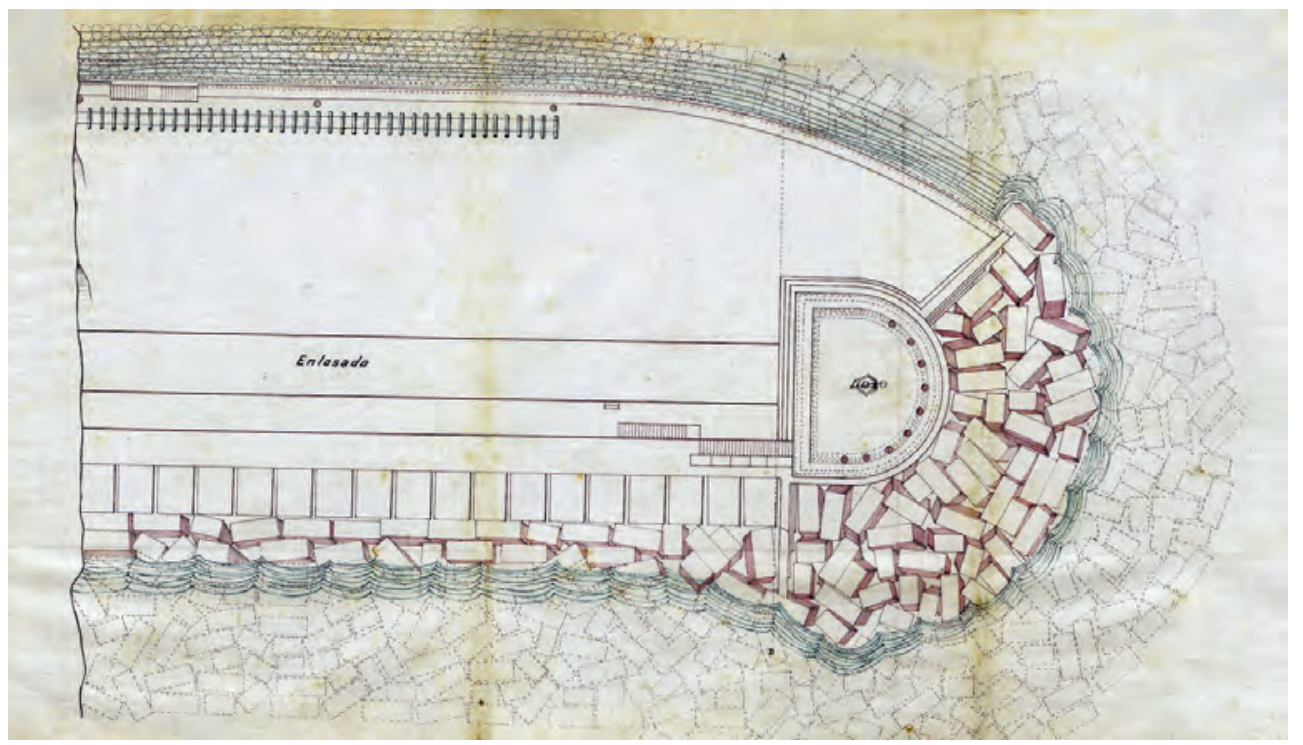

Muelle del morro del dique del Oeste, proyecto de mejora del puerto de Chafarinas de Manuel Becerra, 1904. Archivo Autoridad Portuaria. 
Se rechazaba la propuesta de Aparici de un rompeolas en la punta norte de la isla del Cong reso, uniendo con escollera la Laja. Para Becerra las obras del "rompeolas" eran innecesarias y de resultados muy dudosos", dado que los temporales del noroeste, no eran los más importantes y, además, no defendían el fondeadero $^{36}$. Por eso, en su pr oyecto, para proteger el fondeadero de los vientos del oeste simplemente se proyectaba el dique atracable y su muelle anexo.

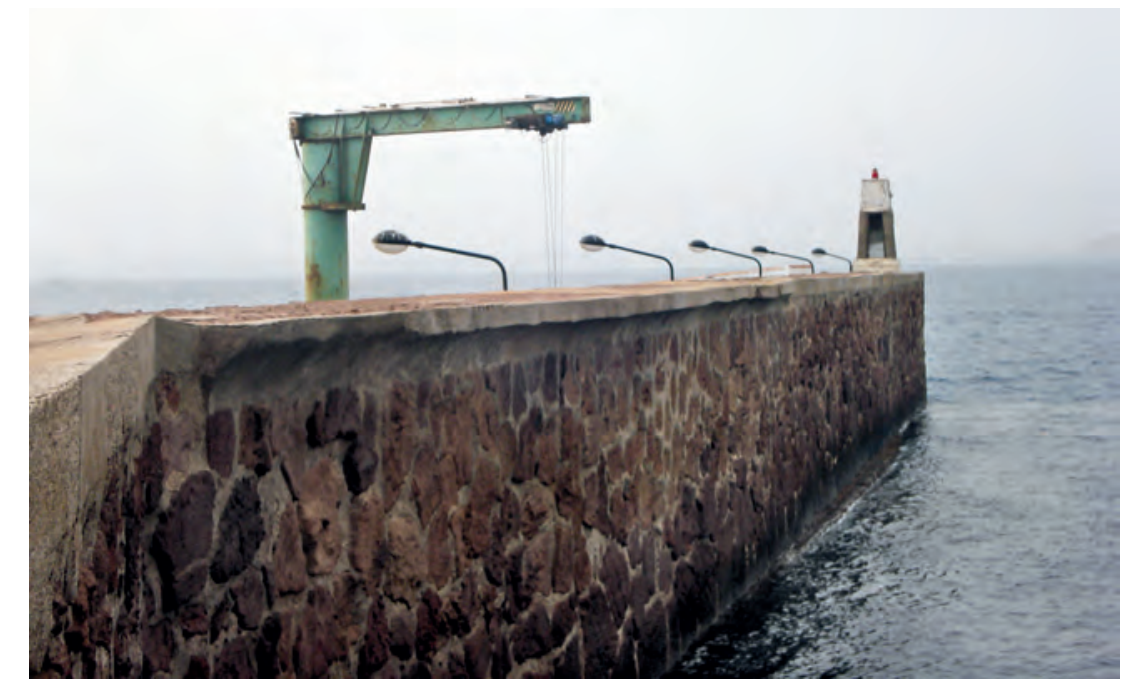

El Titán, en la isla de Isabel II.

Para la ejecución de las obras había que lle var a Chafarinas medios y maquinarias directamente desde la península, arbitrar un sistema de suministro constante de materiales de construcción que no existían en las islas, realizar nuevas edificaciones, construir almacenes y talleres, nuevos aljibes, resolver los problemas de transporte, alojamiento, manutención, aseo y salud de cientos de obreros, etc. En definitiva, un esfuerzo logístico que pondrá a prueba la capacidad de organización de la Junta de Obras del Puerto, pues gran parte de los materiales necesarios para ejecutar estas obras debí an de ser en viados desde la Península (cemento, cal, ladrillo, madera, agua, hierro, etc.) u obtenidos directamente en las islas (arena, piedra para sillería, mampostería y escollera).

36 "Pues con una boca de entrada de 700 metros, entraría la marejada por transmisión lateral; además hay que observar que dicha boca quedaría orientada al NE, es decir, dando franca entrada a la marejada del largo más temible”. 


\section{b) Las primeras obras: por administración.}

La ilusión de los melillenses y sus autoridades por disponer de un puerto en Melilla y Chafarinas no venía sólo motivada por la necesidad de una infraestructura tan vital para el desar rollo y seguridad de la ciudad. La grave crisis económica que vivía el país y el fenómeno migratorio que sufrió la ciudad, había disparado el paro obrero y provocado una situación de emergencia social que sólo podía ser paliada con la mano de obra que supuestamente absorberían las obras del puerto.

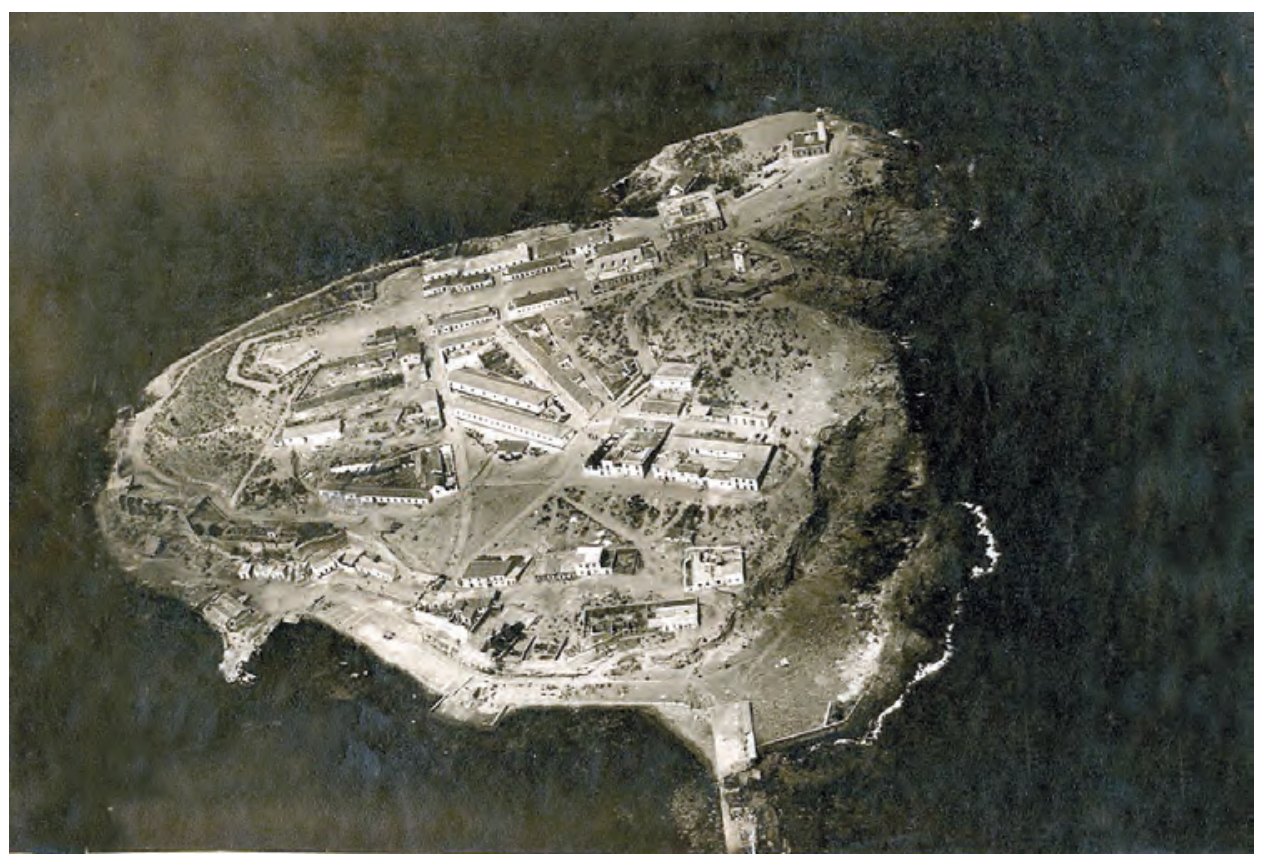

Vista aérea de la isla de Isabel II anterior a la construcción del Titán. FCOML.

El retraso en la adjudicación de los pr oyectos y el paro que sopor taba la ciudad llevó a las autoridades locales a solicitar al Ministio de Fomento que autorizara el comienzo de las obras por administración mientras se subastaban los proyectos, como único medio para r esolver la tensión social y rebajar las alarmantes tasas de paro. De este problema se hacía eco El Telegrama de Melilla, de 7 de febrero de 1907, cuando informaba de la adjudicación de las obras y de la esperanza que habían despertado entre los obreros de la vecina ciudad de Málaga. El 23 de marzo el mismo diario escribía que muchas familias del sur se dispo- 
nían a venir a Melilla a demandar trabajo en el puer to, aunque lamentaba que dichas expectativas no fueran a verse cumplidas, dado que la obras que se construían por administración estaban dando ocupación a unos 150 oberos en Chafarinas y a unos 160 en el de Melilla y el número máximo de puestos de trabajo que se crearían no sería super ior a 500. En efecto, desde el comienzo de 1906 no habían parado de llegar obreros a la ciudad y a pesar de las obras del puer to el número de parados era m uy alto, de modo que los que llegaban difícilmente podían encontrar trabajo.

Las obras del puerto dieron comienzo en enero de 1906, por administración ${ }^{37}$, con el desbroce y preparación para la explotación de canteras, explanación para la construcción del taller de bloques y comienzo de las obras del dique del nordeste. El 17 de ener o salía para las islas la pr imera expedición formada por 53 obreros, un listero y dos capataces, comenzando los trabajos de desbroce de las canteras al día siguiente. A mediados de febrero, ya con 91 obreros trabajando, se iniciaron las obras del taller de bloques, acometiendo su explanación y la construcción de los muros que lindaban con el mar.

Ante la carencia de viviendas en las que alojar a los numerosos obreros, la Junta solicitó $^{38}$ a la Comandancia Militar la cesión de locales para su alojamiento La Comandancia, cedía a los pocos días la na ve existente junto al Cuar tel de Penados. Unos meses más tarde, ante el incr emento de trabajadores, también cedería parte del denominado Cuar tel de Obreros en el cual se realizar on las obras necesarias para adaptar ocho o diez viviendas para las $\mathrm{f}$ amilias ${ }^{39}$. Junto a estas instalaciones, una vez que se iniciaron los trabajos por parte de la Compañía Trasatlántica, se construirían por ésta, previa autorización de la Junta y de la Comandancia Militar, un barracón de $500 \mathrm{~m}^{2}$ en la isla de Isabel II y otro de 250 $\mathrm{m}^{2}$ en la del Rey para viviendas para obreros. Estas instalaciones fueron desalojadas una vez terminadas las obras, derribándose los barracones.

37 Se autorizaron por Orden del Ministerio de Fomento de fecha 5 de enero de 1906.

38 Escrito de 13 de enero de 1906.

39 Expediente $n^{\circ}$ 10. Año 1906. Habilitación por el Ramo de Guerra de locales, en Chafarinas, para viviendas del Sr. Ayudante y Obreros de la Junta y petición por la Compañíatrasatlántica de $500 \mathrm{~m} 2$ de terrenos en la isla de Isabel II y 250 metros en la del Rey para viviendas para obreros. Archivo de la Autoridad Portuaria. 




Deposito de carbón. Memoria de la Junta del Puerto, 1909.

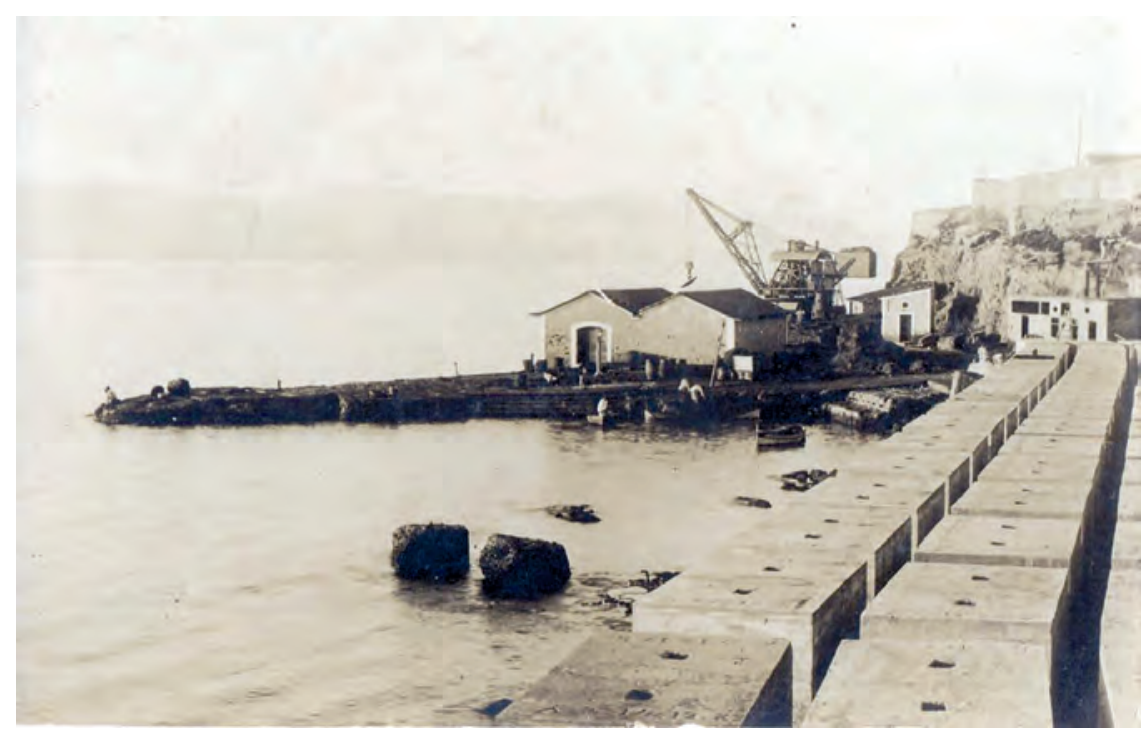

Construcción del dique Noroeste, 1910.

Manuel Becerra había demostrado a lo largo de su manda to una especial sensibilidad por los problemas sociales, y especialmente por el desempleo que padecía la ciudad, de modo que mientras se ejecutaban las obras por administración, ante la falta de material y maquinaria para acometerlas y para no pararlas, 
con el impacto que tendría en el par o, propuso la primera modificación de su proyecto que a la larga se presentaría como poco afortunada. Esta reforma consistió en reducir en una parte del dique del nordeste el espesor de hormigón en los bloques artificiales, que sólo era de una hilada, enrasando con hormigón en masa moldeado in situ con tableros y aumentando la defensa de boques naturales de más de seis toneladas. Con esta solución, aunque el dique dejaba de ser atracable, se podían continuar las obras y a tender a la numerosa mano de obra que en aquellos años llegaba a Melilla en avalancha.

En el mes de abril, una vez realizados los primeros trabajos, comenzaban las obras de construcción del dique del nordeste, aprovechando parte de las obras militares.

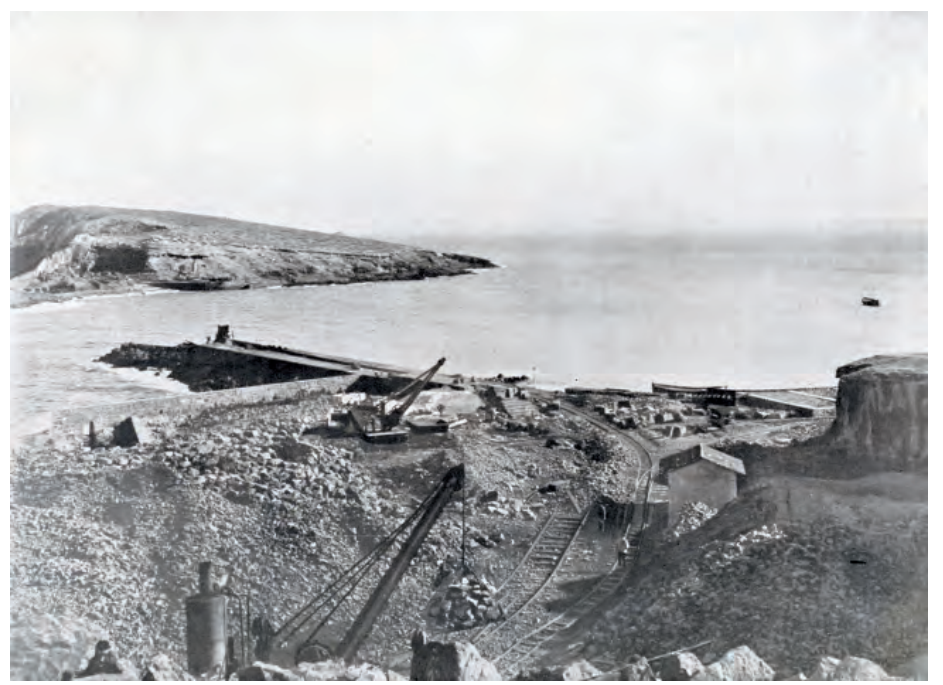

Avance de las obras del muelle de unión. Dique Noroeste, Memoria de la Junta del Puerto, 1909.

\section{c) Las subastas y sus obras.}

Tras dos subastas desiertas ${ }^{40}$, por Real Decreto de 7 de octubre de 1906 se autorizó el concur so para ejecutar estas obras adjudicándose ${ }^{41}$ a la Compañía

40 Aprobados el 13 de febrero de 1903 y 27 de enero de 1906, respectivamente, los proyectos de las obras de los puertos de Melilla y Chafarinas, se anunció con fecha 21 de enero de 1906, la subasta, con un plazo de ejecución de seis años,que quedó desierta por falta de licitadores. Tras una modificación de las condiciones económicas, fueron licitadas las obras nuevamente el 13 de junio de 1906, quedando por segunda vez desiertas.

41 Por Real Orden de 14 de marzo de 1907 
Trasatlántica Española de Navegación. Una particularidad de las subastas y del posterior concurso fue que las obras del puerto de Chafarinas se englobaban en las obras del puer to de Melilla, sin separación de material y maquinaria; como un único proyecto.

El 9 de abril de 1907 se organizaba en Melilla una fiesta para celebrar la adjudicación de las obras, con banda de música, engalanado de balcones y calles, y una generalizada algarabía compartida por autoridades, empresarios, trabajadores y prensa. Seis meses más tarde, a partir del 30 de septiembre de 1907, ya por el sistema de contra ta, tomaba las $r$ iendas de las obras la Compañía Trasatlántica, llegando a la ciudad en los siguientes meses numer osos vapores con la maquinaria y materiales necesarios para construir ambos puertos. La llegada de los vapores y su carga ( $g$ rúas, material ferroviario, elementos para la central eléctrica, hormigoneras, trituradoras, depósitos) adquiría tal relevancia que era informada puntualmente por la prensa con todo lujo de detalles.

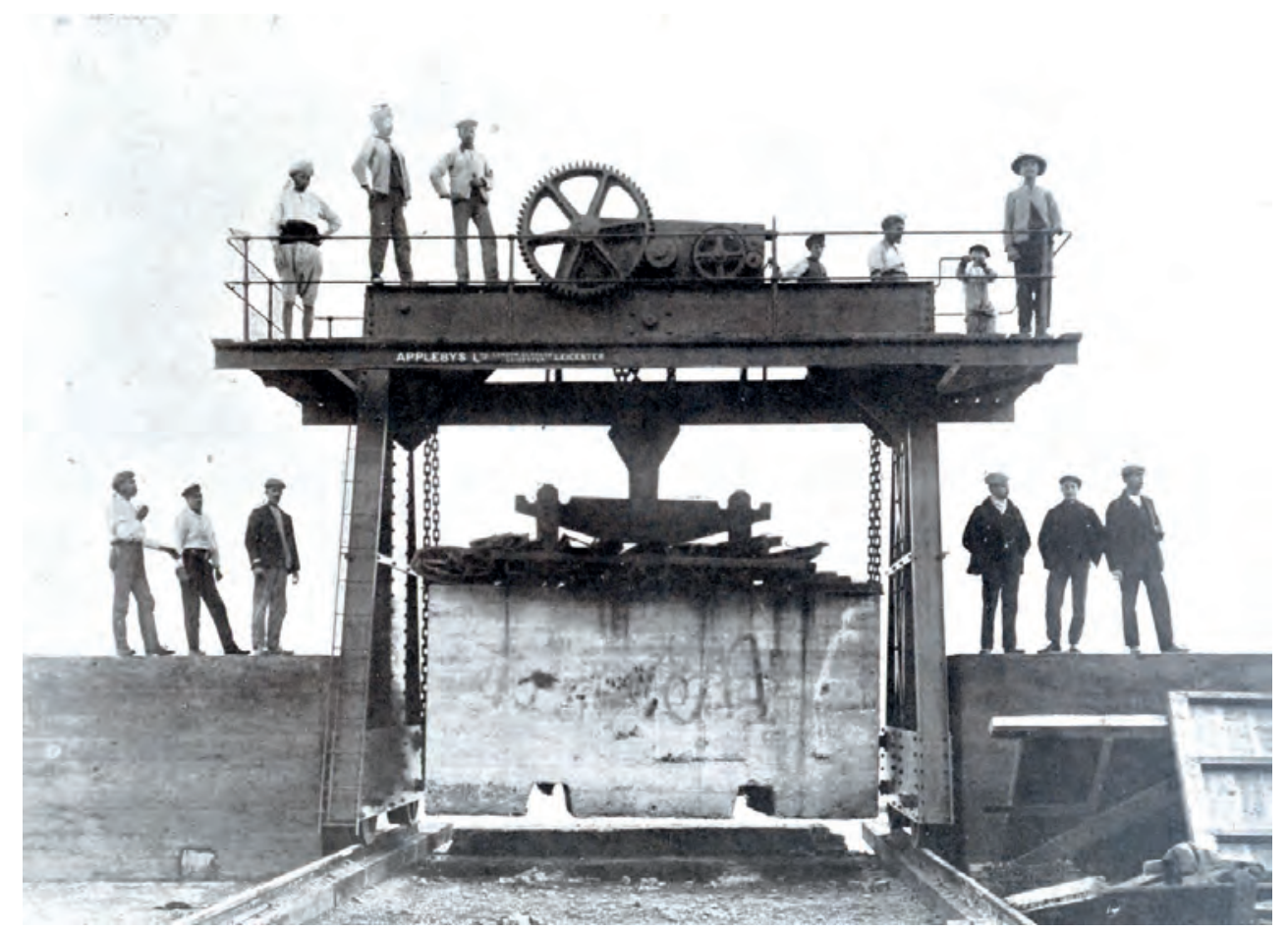

Todo el material y las maquinarias llegan en la carga de los vapores que parten desde Melilla. Grúa Goliat. Memoria de la Junta del Puerto, 1909. 
Las obras del puerto de Chafarinas fueron subcontratadas a su vez por la Compañía Trasatlántica con Antonio Rodríguez Arango, José Escriña y Francisco LópezTrío que fueron los que las ejecutaron bajo la dirección de la citada compañía.

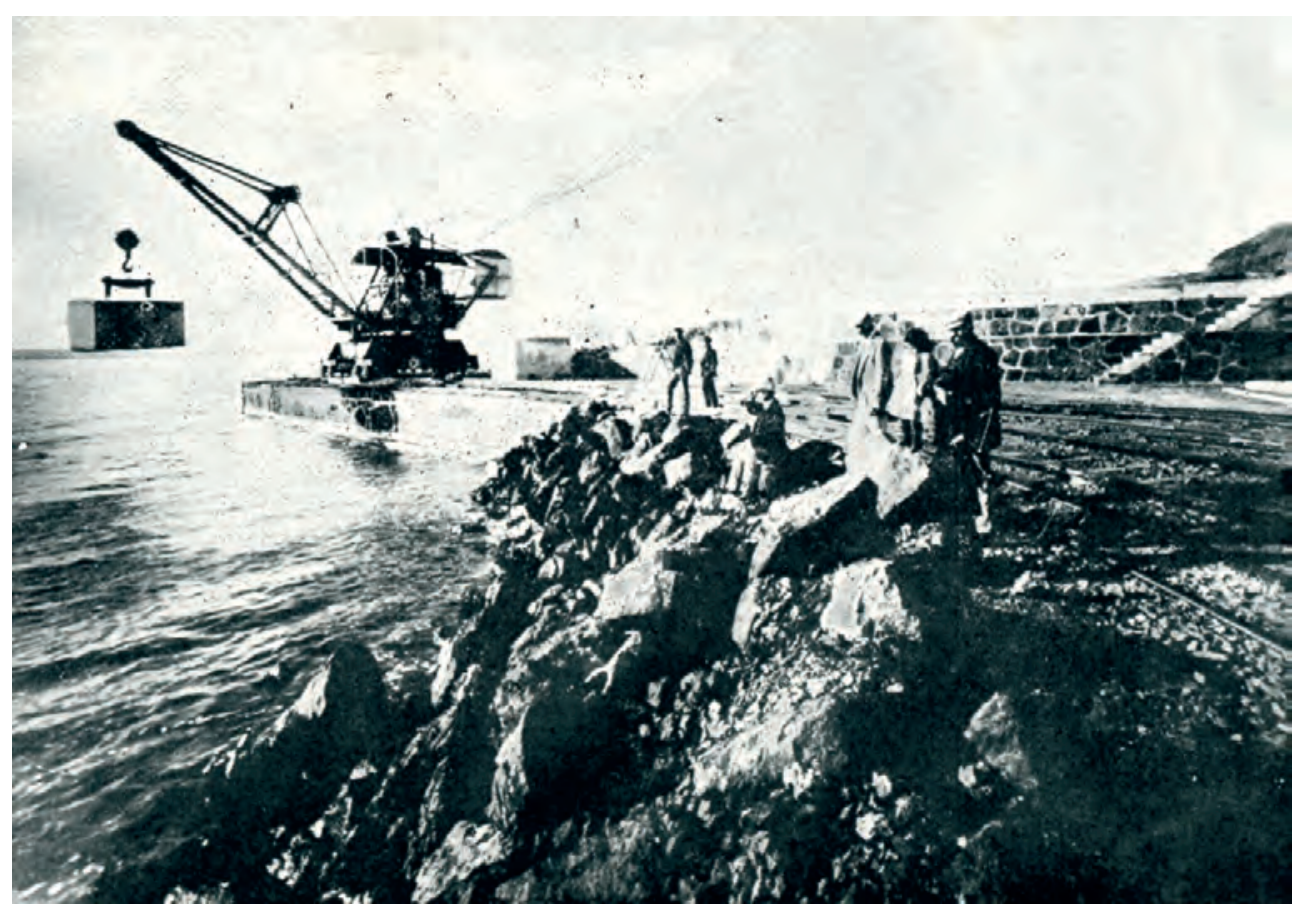

Construcción del dique Oeste, 1911.

A diferencia de Melilla, las obras en Chafarinas no sufrirían grandes retrasos, de modo que en abril de 1909 el cierre del freo chico estaba muy avanzado y se había cubierto la mitad de la distancia entre las dos islas. Funcionaba a pleno rendimiento la trituradora, la quebrantadora, la hormigonera y las grúas Titán y Goliat. De este modo el 17 de abr il de 1910 estaban constr uidos más de dos tercios del dique y el 17 de noviembre del mismo año quedaban unidas las islas Isabel II y el Rey, terminando el dique y cerrado el puerto. Según informaba El Telegrama de Melilla vecinos y guarnición cruzaron de una isla a otra felicitando a la empresa por una obra que se consideraba fruto del talento y del trabajo. Chafarinas, para el periódico, contaba ya con un puerto segurísimo y cerrado a todos los vientos, "siendo a su vez el más amplio de todo el Mediterráneo". 

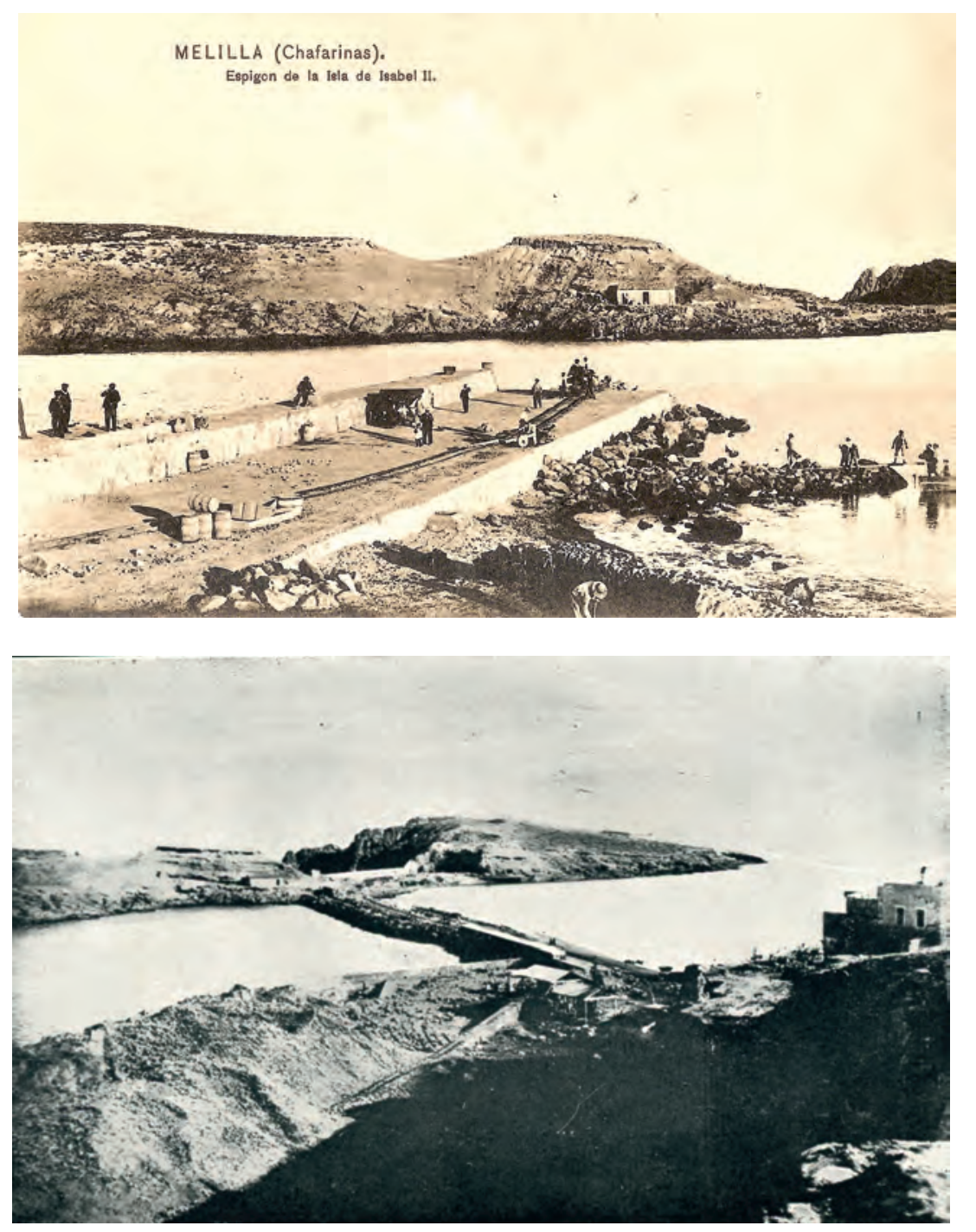

Trabajos de construcción del muelle de unión entre las dos islas entre 1910 y 1911.

En 1908 se había apr obado el "Proyecto reformado de las obr as de mejora del puerto de Chafarinas", introduciendo dos variantes en el proyecto original. La primera extendía la anterior modificación al resto del dique, reduciendo su sección, consiguiendo con ello un ahor ro en los costes que per mitía a su vez abordar sin incremento alguno la segunda v ariante, consistente en aumentar la long itud del dique del oeste unos cuar enta metros, aumentando con ello tanto la superficie atracable de su muelle como la superficie abrigada del puerto. La modificación, a 
juicio de Becerra, no aumentaba la posibilidad de averías en los temporales extraordinarios, pues según la gente del lugar los temporales de 1907 habían sido los más fuertes que habían visto nunca y, sin embargo, la obra ejecutada no había sufrido desperfecto alguno, pues la punta nor te de la isla del Re y defendía al dique del nordeste de los temporales del pr imer cuadrante, que eran los m ás importantes, concluyendo que en el freo que se trataba de cerrar la marejada no tenía tanta importancia. Además, como la obra ejecutada con esta nu®a solución en una parte del dique del nordeste había esistido los embates de los temporales de los dos últimos años, llegó a la conclusión de que estando la zona objeto de modificación más al este, estaría todavía mejor defendida por la isla del Rey ${ }^{42}$.

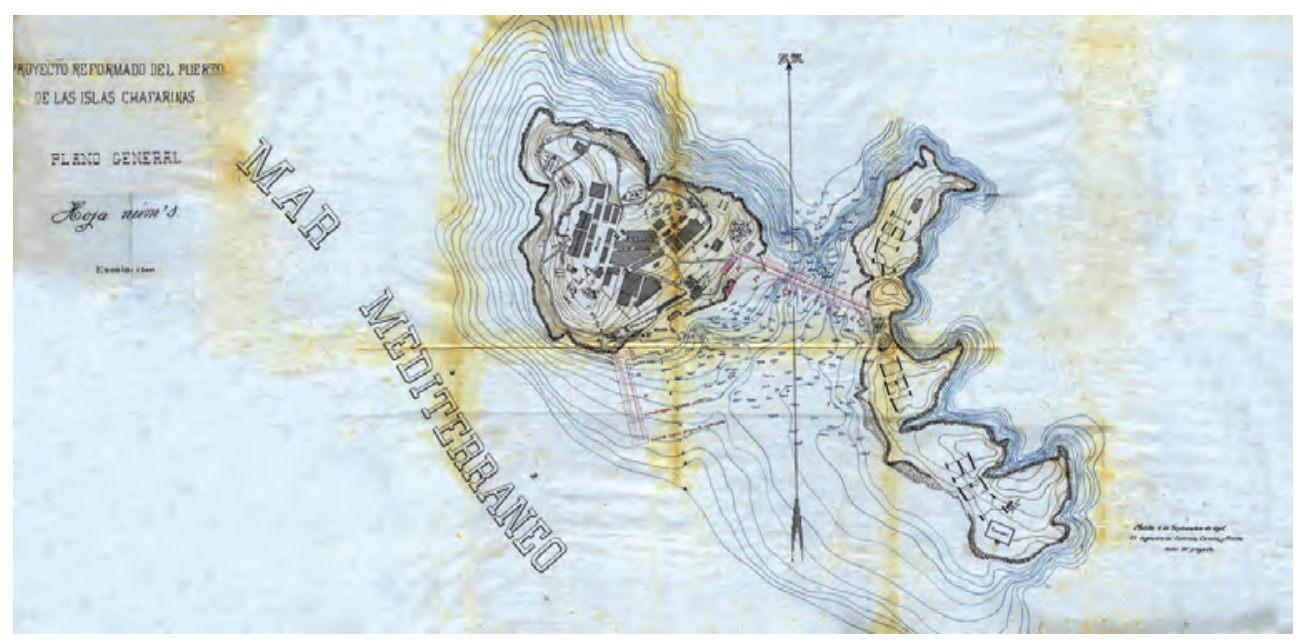

Proyecto reformado del puerto de las Chafarinas en el que se ampliaba la longitud del dique del Oeste con el fin de mejorar el atraque. Manuel Becerra, 1907. Archivo Autoridad Portuaria.

42 Becerra explicaba tal modificación con las siguientes palabras"la enseñanza de la explotación de aquellas canteras después de año y medio , nos per mite asegurar la posibilidad de extraer el númer o de bloques naturales de 5 toneladas necesarios para la ejecución de las obras proyectadas y mayor número si fuera preciso. Fundándonos en esto y en la conveniencia de aumentar la longitud del dique del oeste, como se indicaba en el ante-proyecto y en los informes de Guerra y Marina, presentamos una pequeña reforma en la fábrica del Dique de NE por haber comprobado que los fuetes temporales del año pasado y el actual que las escolleras defendidas con un manto de bloques naturales de 5 toneladas no han sufrido el menor daño. Por dichas razones, proponemos para sección del dique del NE la apıobada para el puerto de Melilla con la variante de suprimir los bloques artificiales de defensa, por haber compr obado que no son necesar ios, sustituyéndolos por bloques naturales de 5 toneladas. Con la economía que supone esta supresión proponemos la prolongación del dique del oeste, dándole la misma sección que la aprobada, consiguiéndose un total aumento en el área o superficie de agua abrigada, 56 metros más de muelle atracable”. 
Con esta modificación, se consiguió una economía de 250.000 pesetas, a pesar de prolongar en 75 metros el dique del oeste; aunque, como el tiempo mostraría, la decisión fue poco afor tunada, pues con ella Becer ra tuvo que renunciar a las conclusiones que como técnico había $r$ ecogido en sus anter iores proyectos, presionado seguramente por las autor idades locales y nacionales ${ }^{43}$, para que se pudiera alargar la extensión del dique del oeste sin incremento presupuestario y dirigir los recursos al puerto de Melilla.

Dos años después, en 1910, el criterio había cambiado y ya no se consideraba necesario darle al dique del oeste los 175 metos de longitud previstos en el proyecto reformado, estimándose bastante unos 100 metros. Este cambio se justificaba en que el puerto no sería nunca comercial y sí sólo de efugio, pero sobre todo en que la Junta de Fomento carecía de recursos y los pocos que manejaba en esos momentos (la subvención del Estado de 500.000 pesetas y unas 100.000 pesetas de ingresos por arbitrios) tenía que dedicarlos al puerto de Melilla cuyas obras estaban muy retrasadas y se consideraban más urgentes y necesar ias para los intereses de España en la zona.

\section{d) Rescisión de las obras y su terminación por administración.}

Por Resolución del Ministerio de Fomento, plasmada en un Real Decieto de 7 de abril 1911, se acordó que fueran rescindidas las obras a la Compañíarasatlántica y terminadas por administración por la Junta de Obras del Puer to. La causa de la resolución hay que buscarla en las obras del puer to de Melilla, pues aunque las obras del puerto de Chafarinas llevaban cierto retraso sobre los plazos previstos, lo cierto es que se encontraban mucho mas avanzadas que aquellas.

La Compañía Trasatlántica había comenzado las obras del puerto de Melilla el 6 de octubre de 1907, lo que unido al plazo de ejecución de ties años hacía que las mismas tuvieran que estar terminadas el 6 de octubre de 1910. Sin embargo el retraso era tan considerable que poco antes de esta fecha, los trabajos en el mar eran insignificantes. A principios de 1910, ya fuera por la paralización de las obras, por la campaña de 1909 (unos siete meses y medio) o por razones

43 La petición de las autoridades locales, Comandancia Militar, está perfectamente documentada y la de las autoridades nacionales se deduce del hec ho de que el proyecto reformado fuera aprobado en el Ministerio de Fomento a pesar de contar con el informe desfavorable del Consejo de Obras Públicas. 
organizativas de la propia contrata, lo cierto es que las obras del puerto de Melilla apenas habían avanzado.

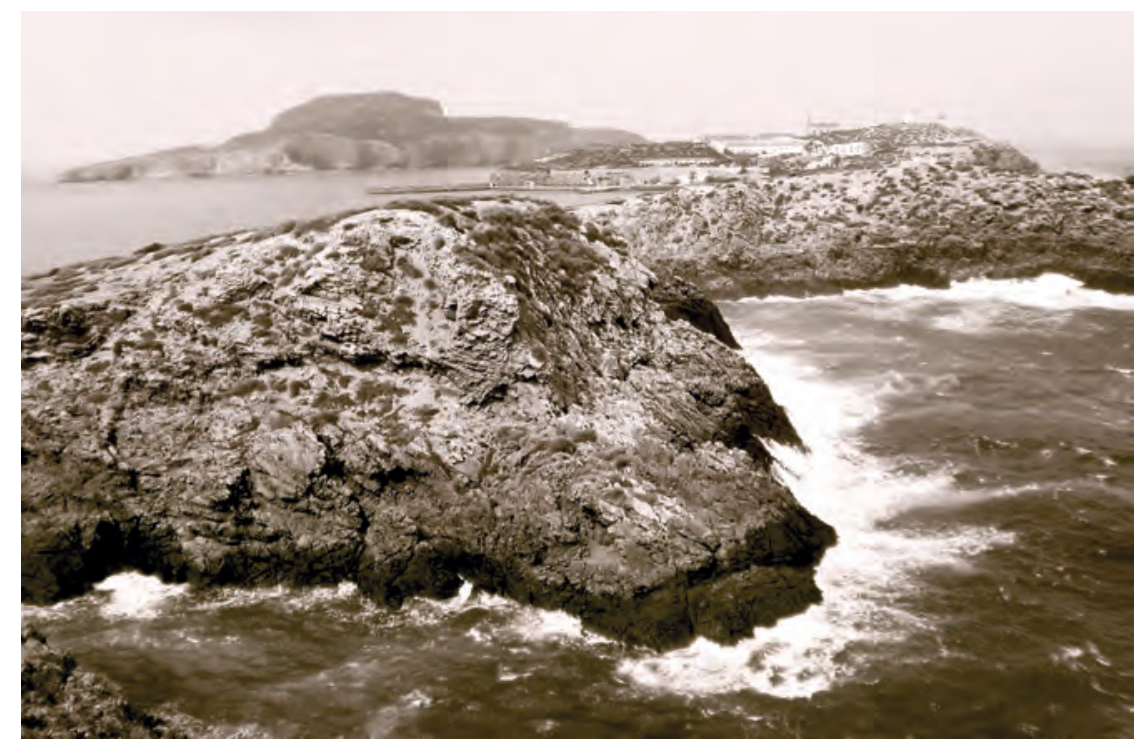

Vista de la isla del Rey, al fondo la de Isabel II y la del Congreso. Fuente: José María Peñuela.

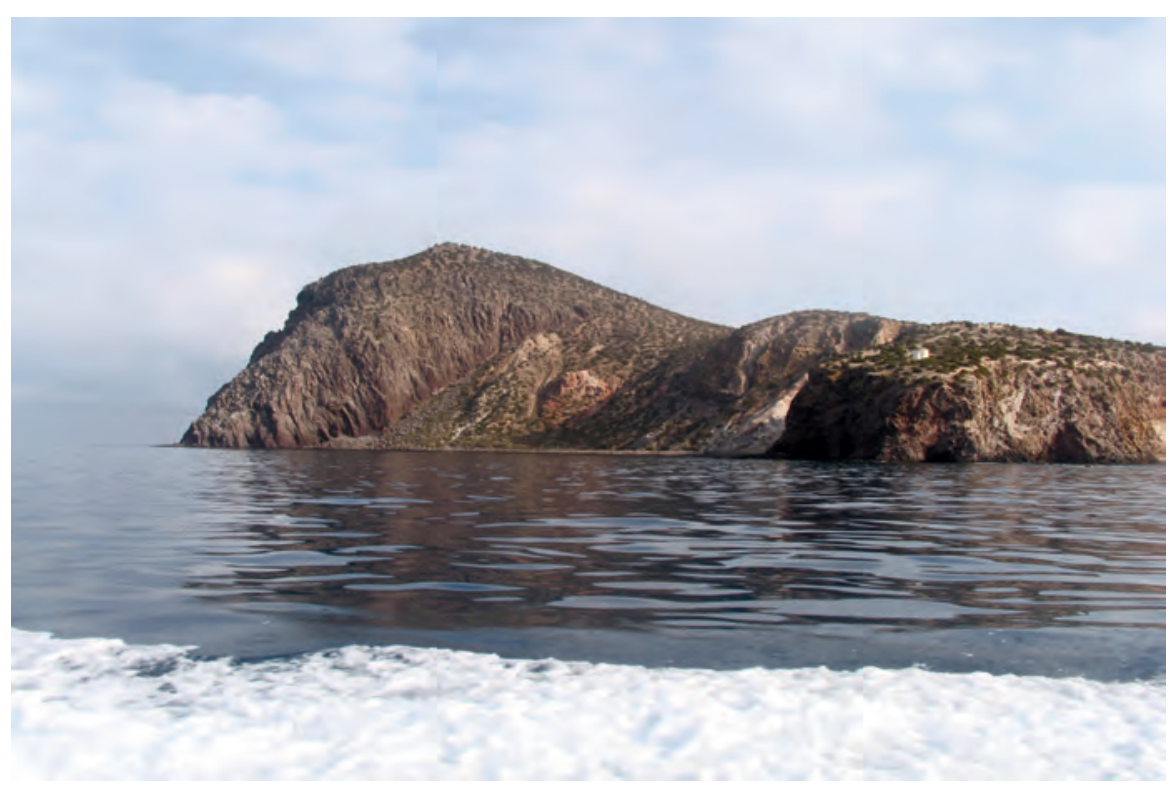

Vista de los acantilados al oeste de la isla del Congreso. 
En el momento de la resolución, el contratista había terminado en el puerto de Chafarinas la infraestructura del dique nordeste, parte de su espaldón y plataforma, y construido una parte del dique del oeste. Junto a estas obras principales, se habían construido obras accesorias pero de vital impor tancia para la construcción del puerto como todas las referentes al taller de bloques, obras de demolición y realce de la muralla, muro de defensa de la ensenada la Sar tén, explanaciones, caminos, casas para obr eros, casa oficina, polvorín, almacenes varios, etc. La liquidación de las obras obligó también a un inventario de la maquinaria y herramientas adscritas a las obras que tras su valoración serían abonadas al contratista y utilizadas por la Junta de Fomento. Entre esta maquinaria se encontraban diferentes grúas, hormigoneras, trituradoras de piedra, locomóvil, vías con material móvil, cemento, embarcaciones y material de buceo y, en general herramientas varias. En total, la valoración de obras, acopios, maquinaria, herramientas y material diverso ascendió a unas 607.669,94 pesetas. A partir de este momento (1911) las obras fuer on asumidas directamente por la Junta de Fomento, a cuyo cargo quedó la ejecución del proyecto.

Las obras, que se dieron por terminadas a finales de 1913 y fueın liquidadas en febrero de 1914, no consumieron todo el presupuesto porque el dique del oeste no fue constr uido en toda su long itud, dejando pendiente de gastar 279.357,61 pesetas, pues tras la ocupación por las tr opas españolas de la posición del Cabo del Agua, la situación del puer to había cambiado y ya no era tan necesario aumentar la extensión del dique, lo que seguramente justificó, ante la escasez de recursos por la que atravesaba el país y la propia Junta de Fomento, que se redujera finalmente su longitud. Curiosamente las obras de prolongación del dique del oeste, que en 1907 habían sido solicitadas por el Minister io de la Guerra, fueron la causa principal de que se redactara el Proyecto reformado del puerto de Chafarinas, que como vimos sustituyó los bloques hidráulicos por la escollera perdida y que como v eremos fue una de las causas del desastr e o del colapso del dique del nordeste.

\section{e) El gran desastre.}

Tras ocho años de trabajo y apenas un mes después de darse por terminadas las obras, el puerto de Chafarinas iba a ser sometido a su más dura preba. El 11 de marzo de 1914, a las 23 horas, se iniciaba un violento temporal de levante que en apenas dos horas destr ozaría gran parte de las obras de los puer tos de 
Melilla y Chafarinas, hundiría varios buques y embar rancaría más de cuarenta embarcaciones $^{44}$. En Chafarinas se hicieron notar los efectos del temporal, provocando daños ${ }^{45}$ en casi todas las instalaciones de las islas y graves averías en las obras del puer to, partiendo el dique que cer raba el freo c hico, que pasaría a llamarse con los años el "dique roto”.

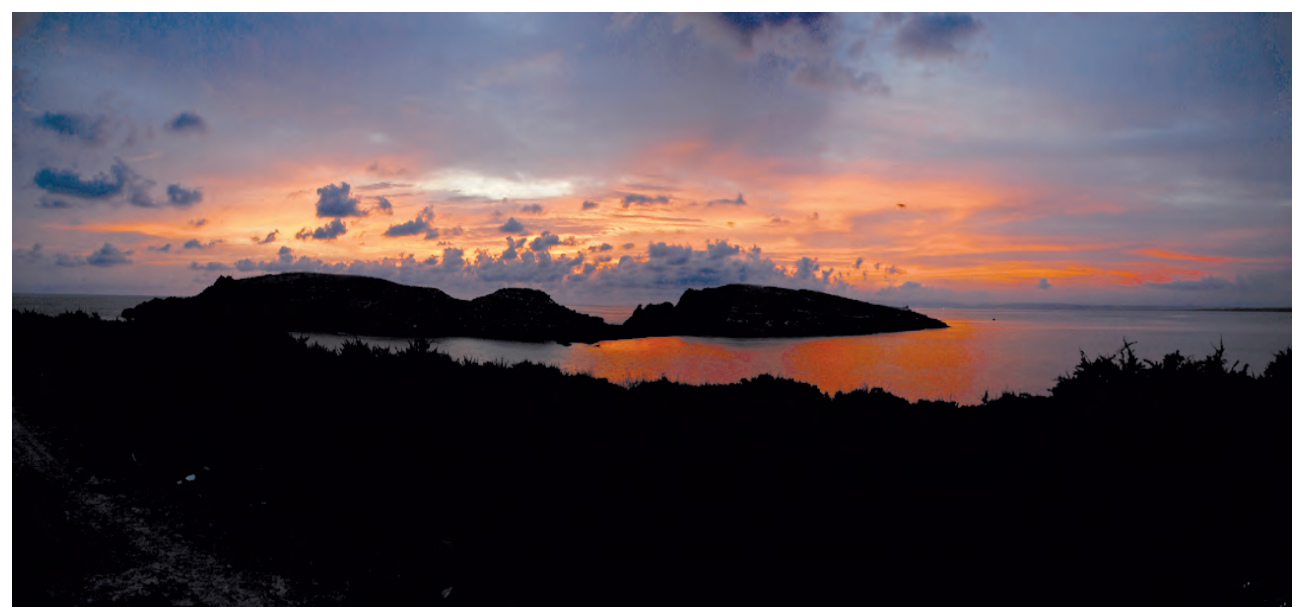

Isla del Rey durante el amanecer veraniego, vista desde Isabel II. Fuente: José María Peñuela.

La crónica del corresponsal de El Telegrama de Melilla, de 15 de marzo de 1914, describía con detalle como se vivió el temporal en las Chafarinas: "el 11 a las 23, se desencadenó sobie esta isla furioso vendaval que a modo de tromba baría cuanto a su paso hallaba. Una hora después el mar estaba imponente, pasando por encima del dique que une las islas del Rey y la de Isabel II, donde se asienta la plaza. A las cinco, se produjo un fuerte ruido, semejante al que precede a los terremotos que pasó en conmoción al vecindario; era el dique que se rompía con estrépito. Todos nos lanzamos a la calle y cuando amaneció, vimos con desconsuelo que el cierre del puerto, el dique de unión de las

${ }^{44}$ Según el que fuera Cr onista Oficial de la Ciudad, Francisco Mir Berlanga, en obra inédita Memoria del Puerto de Melilla- Recopilación Histórica. Melilla, 1986. "La violencia de las olas prorocó tal desastre en las embarcaciones que se encontr aban en la rada que se hundieron los $r$ emolcadores "Rosario", "San Antonio" y


el barco "Europa de Transportes Militares" y fueron a parar a la playa donde quedaron embarrancados el "Leonardo", de bandera italiana, los vapores "Ciudad de Soller", “Arcadia”, "Torremolinos” " "Estopiñan”.

45 "El Temporal. Desde Chafarinas”, El Telegrama del Rif, 15 de marzo de 1914. 
dos islas que medía 250 metros estaba destruido en una extensión de cien metros,el relleno había desaparecido y lo que resta en pié tiene grandes grietas. El trabajo de los hombres de cuatro años, lo destrozó la nauraleza en una hora. La excavación de la cantera que proporcionaba la piedra, estaba inundada, alcanzando las aguas la altura de cinco metros. Las grandes piedras no utilizadas en el puerto, las vagonetas y útiles, cuanto allí estaban almacenadas, fue arrastrado por las olas, sepultándose en el mar”.

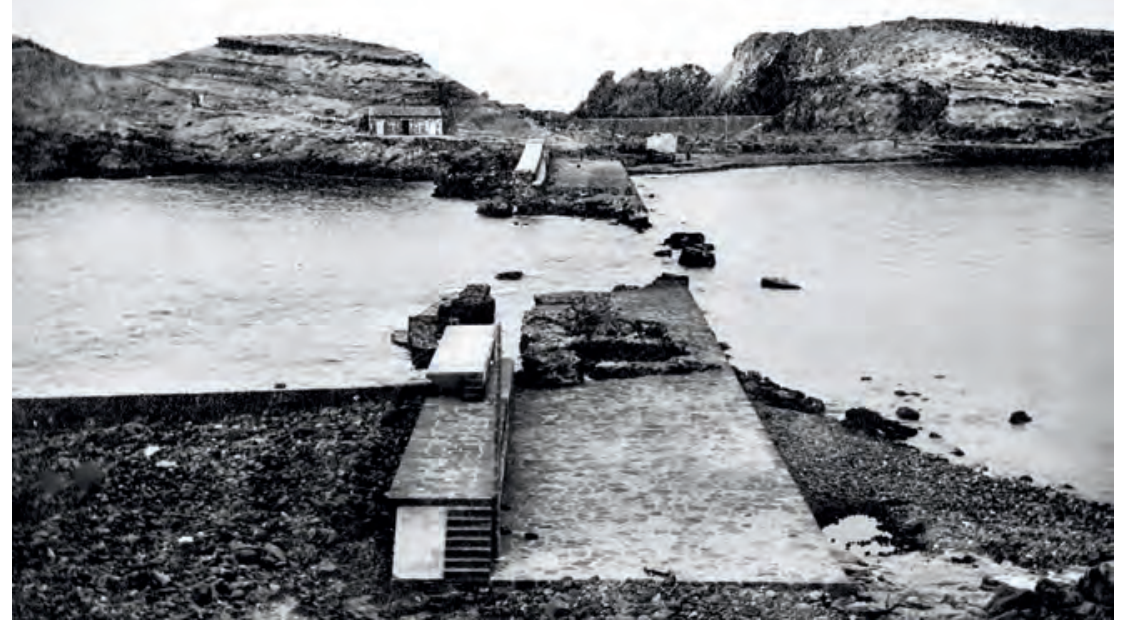

Dique recién destruido por el temporal de 1914 un mes después de terminar su construcción.

El 22 de abril de 1914, apenas un mes después del temporal de marzo , redactaba Manuel Becerra el "Proyecto de reparación de las averías ocasionadas en el dique del NE del puerto de Chafarinas por el temporal de marzo de 1914" y lo elevaba a la superioridad para su aprobación técnica, proponiendo a su vez que su ejecución se realizara con cargo al presupuesto no ejecutado del proyecto original.

Sin embargo, los daños que el temporal había causado en el puer to de Melilla, con la pérdida de la g rúa Titán de 80 toneladas, obligó a desmontar la Titán de 40 toneladas que trabajaba en las Chafrinas y trasladarla a Melilla.Para la Junta de Fomento, con graves problemas económicos en la obras de Melilla (con un problema de paro en la ciudad que días antes había povocado la primera manifestación obrera) Chafarinas pasaba a segundo plano. Además, los reparos de la superioridad a la viabilidad técnica del proyecto y la dificultad para llevar inmediatamente materiales a las islas impidieron que se acometieran con rapidez 
y urgencia las obras de reparación. Este retraso dejó muy debilitada a la infraestructura frente a los próximos temporales y como consecuencia de uno de ellos, en este caso de un largo y fortísimo temporal de poniente, a finales de enero de 1915, las obras terminarían por ser mortalmente dañadas y el dique NE malherido, rompiéndose definitivamente la unión entre las dos islas.

\section{f) Las causas del desastre.}

Manuel Becerra señala como causa del desastr e la inusitada violencia del temporal que según los más viejos del lugar eran supeiores a los que se conocieron en los últimos cuarenta años. Esta versión, unida a que en ese momento los daños no eran todo lo gave que llegarían a ser, hace que las obras que propone se limiten a recrecer la antigua escollera en el manto de defensa del diquę dándole un talud mayor del que tenía en el pr oyecto primitivo y a ejecutar las obras de restablecimiento de la pla taforma y el espaldón según el pr oyecto originario, todo ello con un presupuesto de 99.016,04 pesetas que se proponía fueran imputadas al remanente de la obra originaria que no se había gastado. El proyecto fue remitido a la superioridad para su tramitación y aprobación, sin que en enero de 1915 se hubiera tomado ninguna decisión y fuera dæuelto para su corrección en el mes de abril.

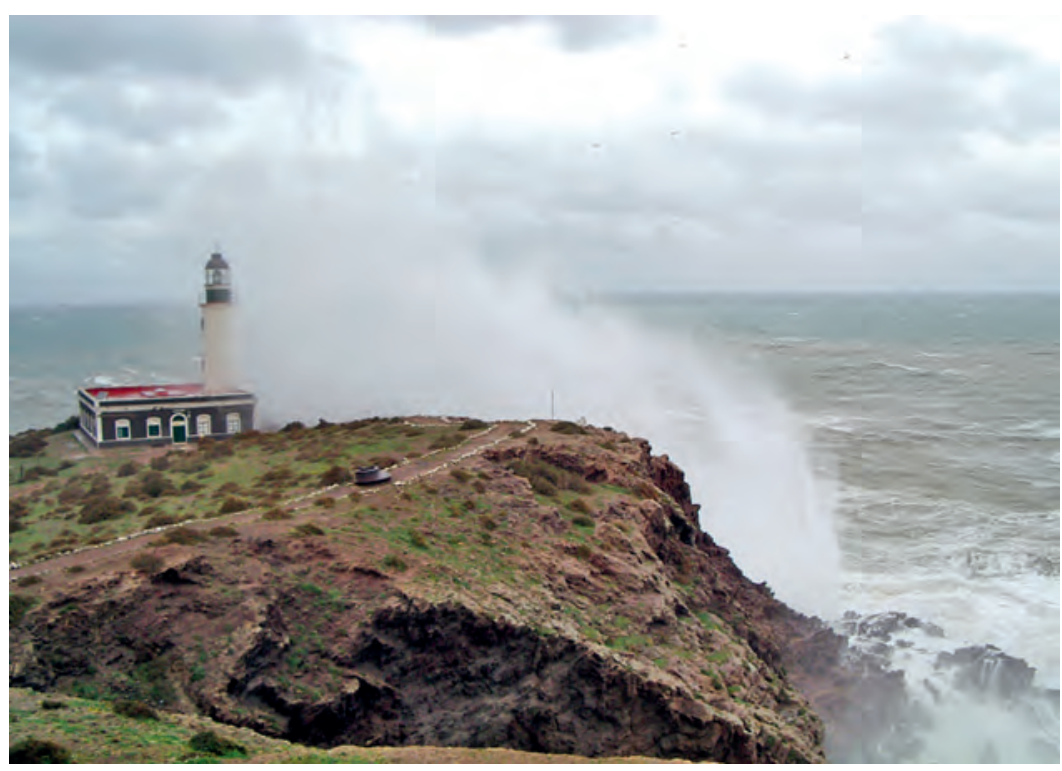

Temporal arreciando sobre la parte noroeste de la isla de Isabel II. 




Fuerte temporal de poniente golpeando contra el dique roto del noreste, al fondo la isla del Rey. Actualidad. Fuente: Javier Díaz.

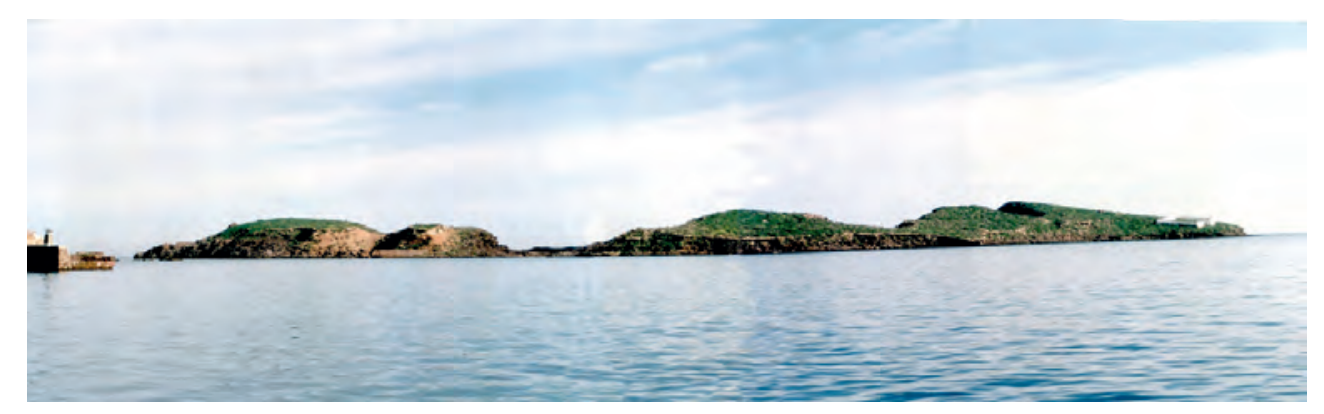

La isla del Rey en un día de calma. 1986.

Las causas probables de la rotura del dique nordeste se recogen en la Memoria del segundo "Proyecto de reparación del dique NE del puerto de Chafarinas" redactado en 1915 por el r ecientemente nombrado Director de la Junta de F omento, José Álvaro Bielza. Este proyecto se redactó por quedar inser vible el anterior pues el temporal de ener o de 1915 causó nue vos daños en la infraestructura e impuso nue vas reparaciones. Bielza pone el acento en dos aspectos . Por un lado, en el hecho de que el proyecto reformado hubiera sustituido, en la defensa exterior del dique, los bloques artificiales por una defensa de escollera, lo que a su v ez había sido desestimado en un infor me del Consejo de Obras 
Públicas. Por otro, a que el perfil del dique constr uido no respetaba el perfil aprobado en el proyecto, siendo una obra muy estable como muro pero no para soportar los empujes hor izontales que desarrollaban las olas al c hocar con él, sobre todo debido a las fuer tes socavaciones a las que estuv o sometido por las resacas y malas condiciones de estabilidad debido a las fuetes presiones, al paramento y per pendiculares, que soportaba en su cor onación. En definitiva, para Bielza la ruina del espaldón tuvo como causa principal la socavación de la escollera que constituía la base del mismo , por los efectos de la $\mathrm{r}$ esaca, tomando taludes mayores a los que inicialmente se le dieron.

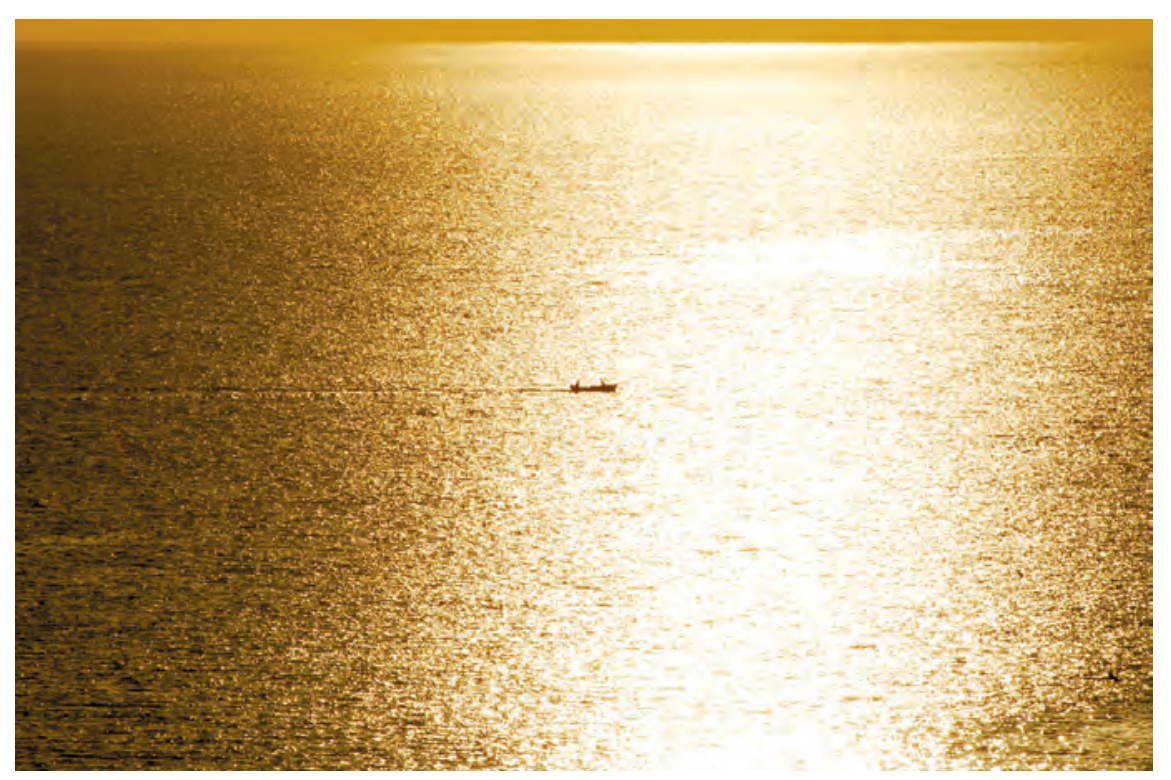

Mar en calma en el archipiélago después de un fuerte temporal. Fuente: José María Peñuela.

La protección exterior del dique, en todos los estudios, incluidos los de Aparici y Becerra, se había planteado con bloques de hormigón artificiales, pues la experiencia demostraba que la defensa de escolleras perdía con el tiempo gan parte de su eficacia, pues las canteras de la isla de Isabel II, de la que se sacaban los materiales para ejecutar las obras, estaban constituidas por rocas eruptivas, muy duras pero no muy compactas ni tenaces, con una composición granujienta que hacía que las piedras perdieran con los embates del mar sus aristas, se convirtieran en cantos rodados y la escollera ter mina por perder gran parte de su eficacia. Además, como los bancos de roca no eran uniformes y tenían bastantes 
vetas y grietas, no fue posible obtener grandes escolleras, de modo que rara vez las piedras alcanzaron las 5 toneladas, como prueba que tras el desastr e no se encontraran en los restos de las obras bloques de grandes dimensiones.

Para Bielza el cambio de bloques artificiales a bloques naturales había sido no sólo imprudente sino incluso temerario, por eso en su proyecto propuso cambios al proyecto primitivo que daban respuesta a las dos causas principales de la ruina del dique: 1) reforzar su perfil y 2) sustituir la escollera natural por escollera artificial, formada por sillares de hormigón de suficiente peso y v olumen $\left(16 \mathrm{~m}^{3}\right)$, salvo en su coronación que serían de grandes bloques de mampostería hidráulica de sección pentagonal y con un volumen de 93,750 $\mathrm{m}^{3}$.

Los cuatro proyectos de Bielza y el quinto de Pascual de Luxan entrarían en largos viajes de ida y vuelta que empezaban en la Junta de Fomento, pasaban a la Jefatura de Obras Públicas de Málaga, al Servicio Central de Puertos y Faros y finalmente al Consejo de Obras Públicas, para acabar en la Dirección General de Obras Públicas que lo remitía de nuevo a la Junta de Fomento para que realizaran las observaciones y modificaciones pertinentes. Así, hasta en cinco ocasiones, en un trayecto que duraría más de diez años, que padeció las consecuencias de las guerras con Marruecos y que terminó por no ejecutarse porque el avance en la obras del puerto de Melilla ya no lo hacía tan imprescindible, la posición de Cabo del Agua era controlada por el ejército español y los recursos económicos de la Junta de Fomento eran escasos y debían de volcarse en el puerto de Melilla que había sufrido graves averías en los temporales de 1914 y 1915.

En 1915, 1916 y 1917 las cantidades invertidas en Chafarinas se limitaron al mantenimiento del dique del oeste, muelle de costa y muelle chico. Por ello, en agosto de 1918, la Junta de Fomento, con su remolcador "Reina Victoria" y barcazas militares, iniciaba el transpor te a Melilla del ma terial utilizado en la construcción del puerto de Chafarinas, incluida la grúa Goliat (1919) que sería utilizada para la construcción de los muelles de Ribera, dado que no era utilizado desde hacía años y, además, era necesario para la constr ucción del puer to de Melilla, cuyas obras aún estaban muy atrasadas.

Abandonado el proyecto, el dique del nordeste se con virtió en el "dique roto» y sus restos fueron desapareciendo con el paso del tiempo por la acción de los levantes y ponientes. En las inmediaciones de donde estuv o el dique sólo quedan unos pocos restos y dos grandes heridas en las islas, justo donde estaban las canteras, que nos dan una idea de cómo Chafrinas se fagocitó a sí misma para poder contar con un puerto. 


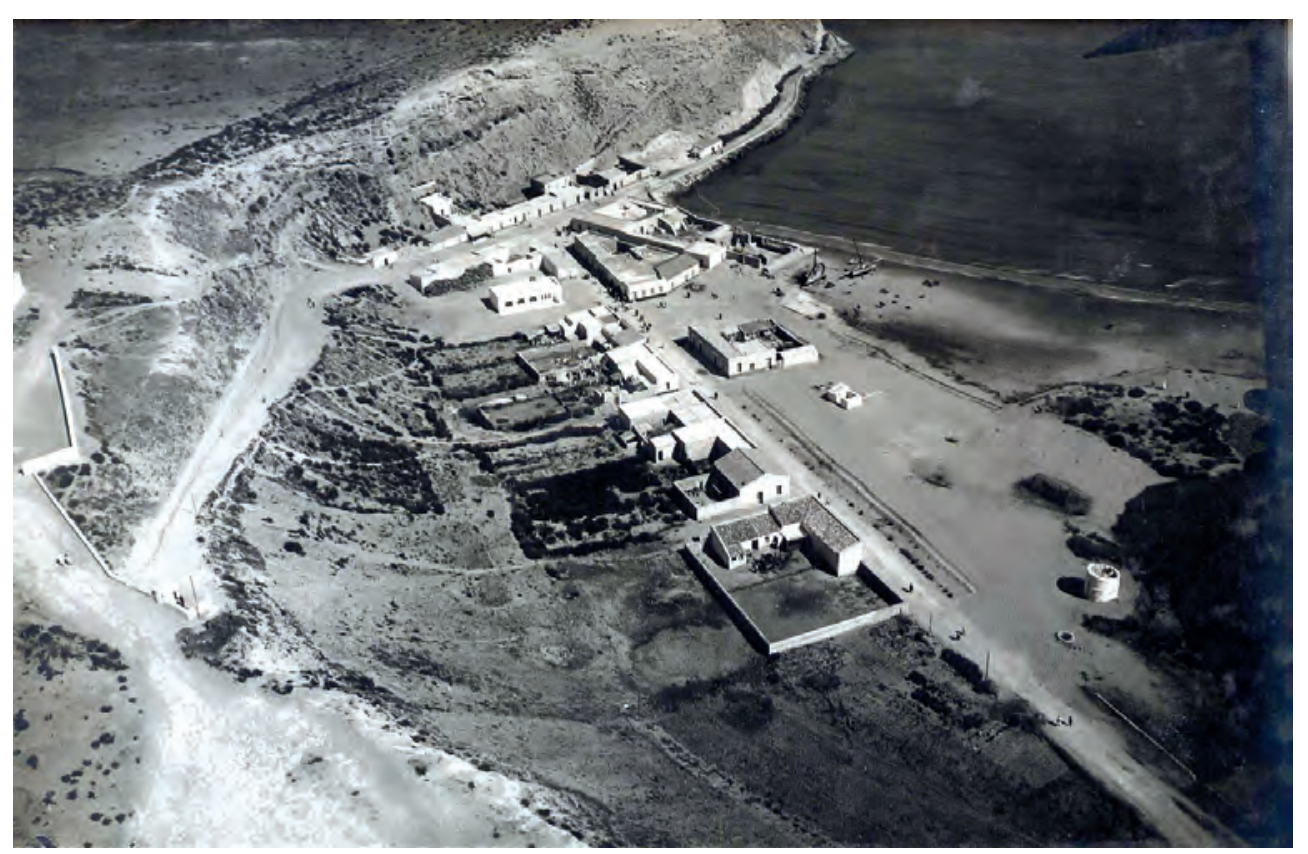

Vista de Cabo del Agua, principios de los años veinte.

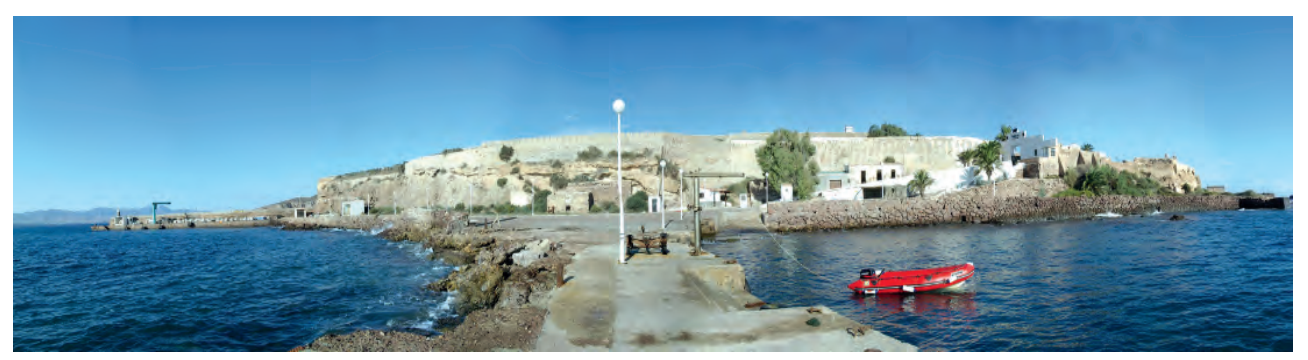

Muelle Chico en la actualidad, vista desde el extremo del espigón. Fotografía Carlos del Campo.

El resto de la obras, es decir, el dique del oeste, el muelle de costa, el pequeño y reconstruido muelle de Lombera y la explanación del taller de b loques, dieron el resultado esperado y han cumplido hasta nuestros días, con pequeñas reparaciones, la función para las que habían sido proyectadas.

\section{g) El puerto de Chafarinas hoy.}

Hoy en día las obras del puerto del Chafarinas son prácticamente las mismas que las construidas a principios del siglo XX.Durante estos cien años apenas se han realizado obras nuevas, salvo las de consolidación, reparación o manteni- 
miento. Si acaso mencionar las realizadas en los años cincuenta del siglo pasado recogidas en un proyecto de ampliación, reparación y pavimentación del dique, embarcadero y varadero y las recogidas en varios proyectos de mantenimiento y reparación del Faro de Isabel II.

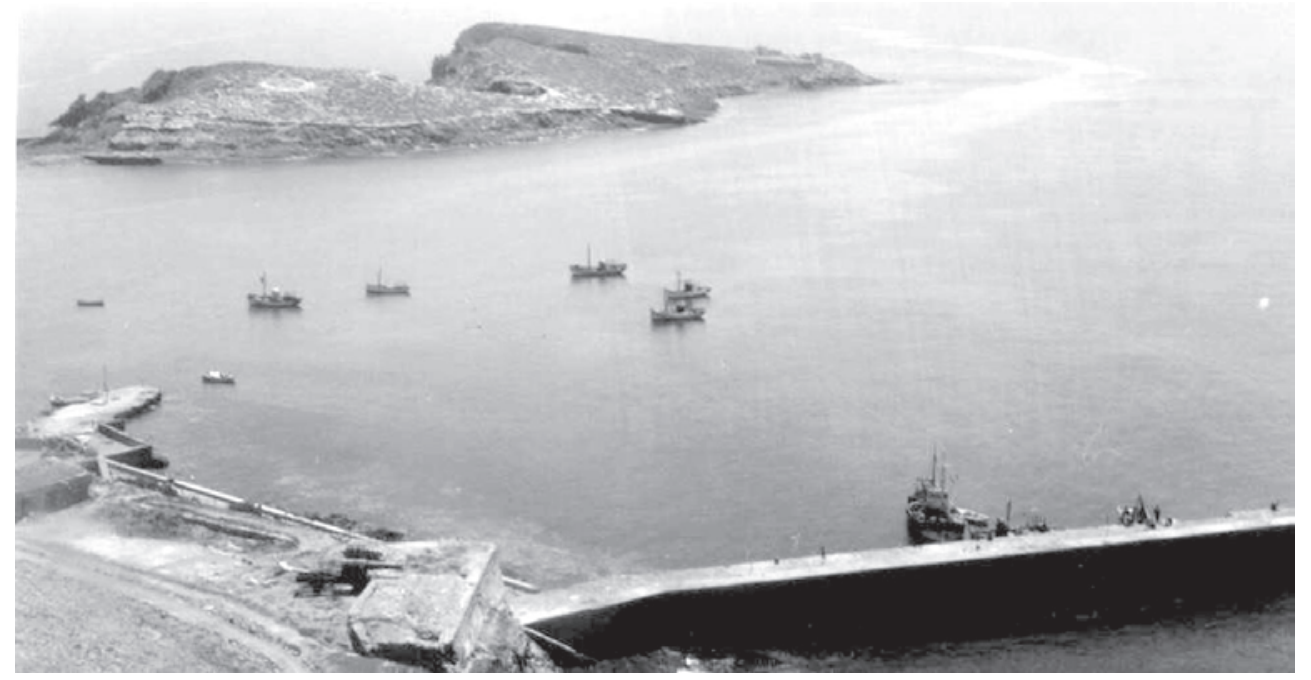

Vista general del muelle Chico y El Titán.

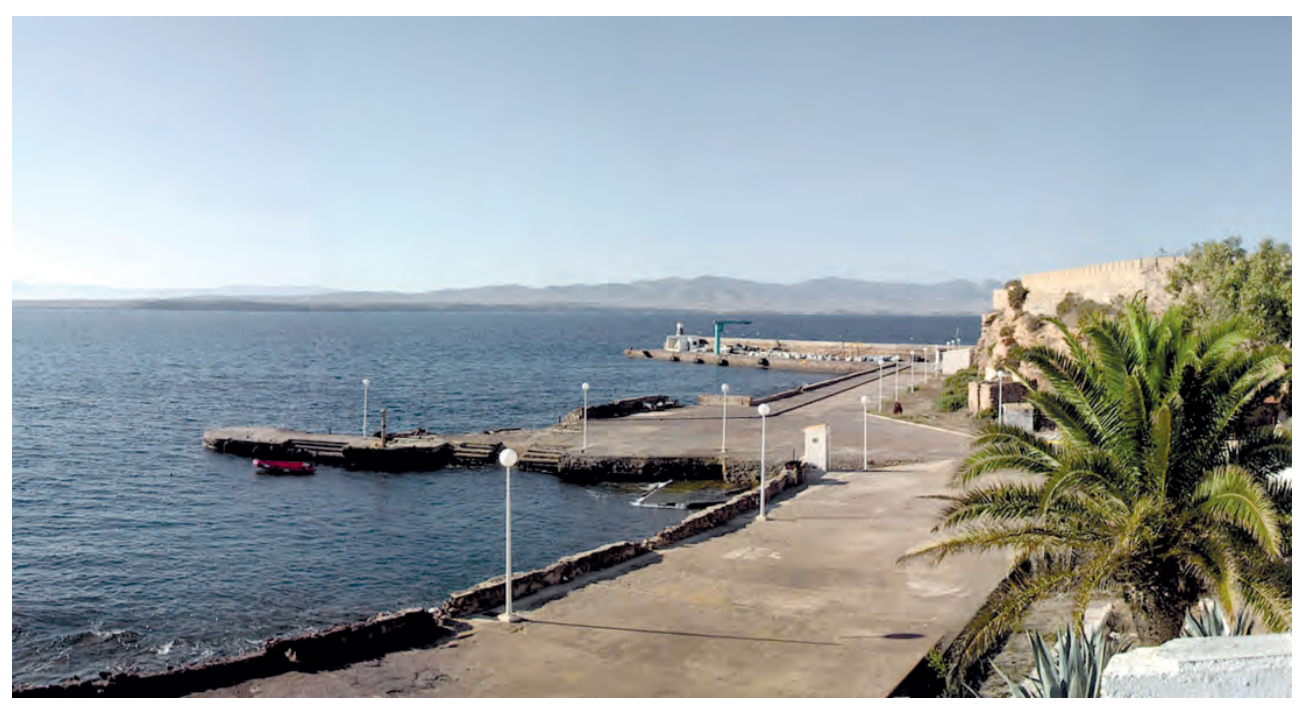

Actualmente la actividad de los muelles en las islas es muy reducida. Muelle chico en primer plano y al fondo el muelle El Titán. 
Este puerto que nunca tuvo carácter comercial, limitó su tráfico portuario al abastecimiento de sus habitantes y a los suministos de la guarnición. De modo, que a medida que las islas fueron perdiendo habitantes y carácter civil, la actividad portuaria fue decreciendo hasta casi desaparecer. De los 736 habitantes censados en 1910 se pasó a los 318 en 1920, a 172 en 1930 y a 113 en 1950 . Hoy, desaparecida la población civil y con ella los buques correos que allí prestaban su servicio, las islas sólo tienen una pequeña pr esencia militar que es a tendida y abastecida regularmente por helicópteros o buques militares.

También hay una instalación per manente del organismo público Parques Nacionales, con una pequeña dotación de técnicos medioambientales. Fuera de estos casos, las islas sólo atienden a la presencia ocasional de los operarios de la Autoridad Portuaria y la pr esencia temporal en la época estiv al de campos de trabajo que compaginan la investigación arqueológica con la limpieza y reparación de antiguos caminos.

La Autoridad Portuaria de Melilla, sucesora de la Junta de Obras del Puerto y de la Junta de Fomento, mantiene estas instalaciones, respecto de las cuales ejerce las funciones que le otorga la legislación vigente y que se limitan al mantenimiento de las infraestructuras portuarias y de las señales marítimas que integran su zona de servicio.

La zona de servicio del puerto, aprobada por Orden FOM/2210/2010, de 19 de julio, califica el puerto de Chafarinas como un área de refugio integrada por las instalaciones situadas en la isla de Isabel II que incluyen el dique del oeste y su muelle "ElTitán", el muelle de Ribera, el embarcadero o Muelle Chico, la rampa de varada, la escollera que discurre bajo el mirador del Mentidero ${ }^{46}$ y el solar del antiguo taller de bloques, hasta llegar al ar ranque del desaparecido dique nordeste, o dique "roto".

A los muelles y rampa de varada se les asigna un“Uso Comercial," limitado al abastecimiento de la isla, y al resto de instalaciones se les asigna un "Uso de Infraestructuras". Se establece una Zona I de aguas, situada en la isla de Isabel II, delimitada por el muelle El Titán, la línea de costa hasta el extr emo este de la escollera que discurre bajo el mirador del Mentider o, el antiguo taller de b loques, la línea imaginaria, paralela al antiguo dique del nordeste, hasta su intersección con la línea imaginaria resultante de prolongar el dique del oeste.

${ }^{46}$ El nombre del mentidero viene de un kiosco que se ubicaba en las inmediaciones. 


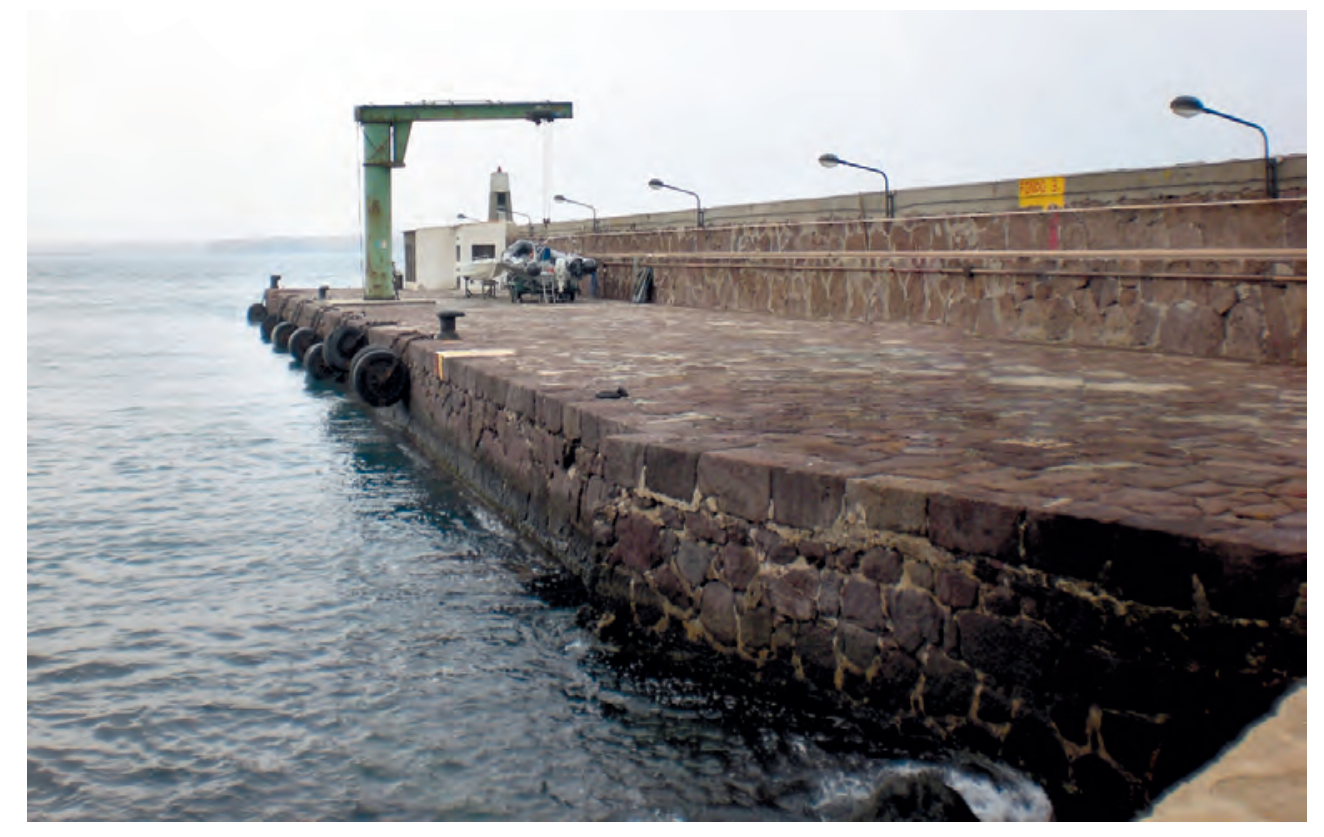

El puerto del Oeste en la actualidad, El Titán.

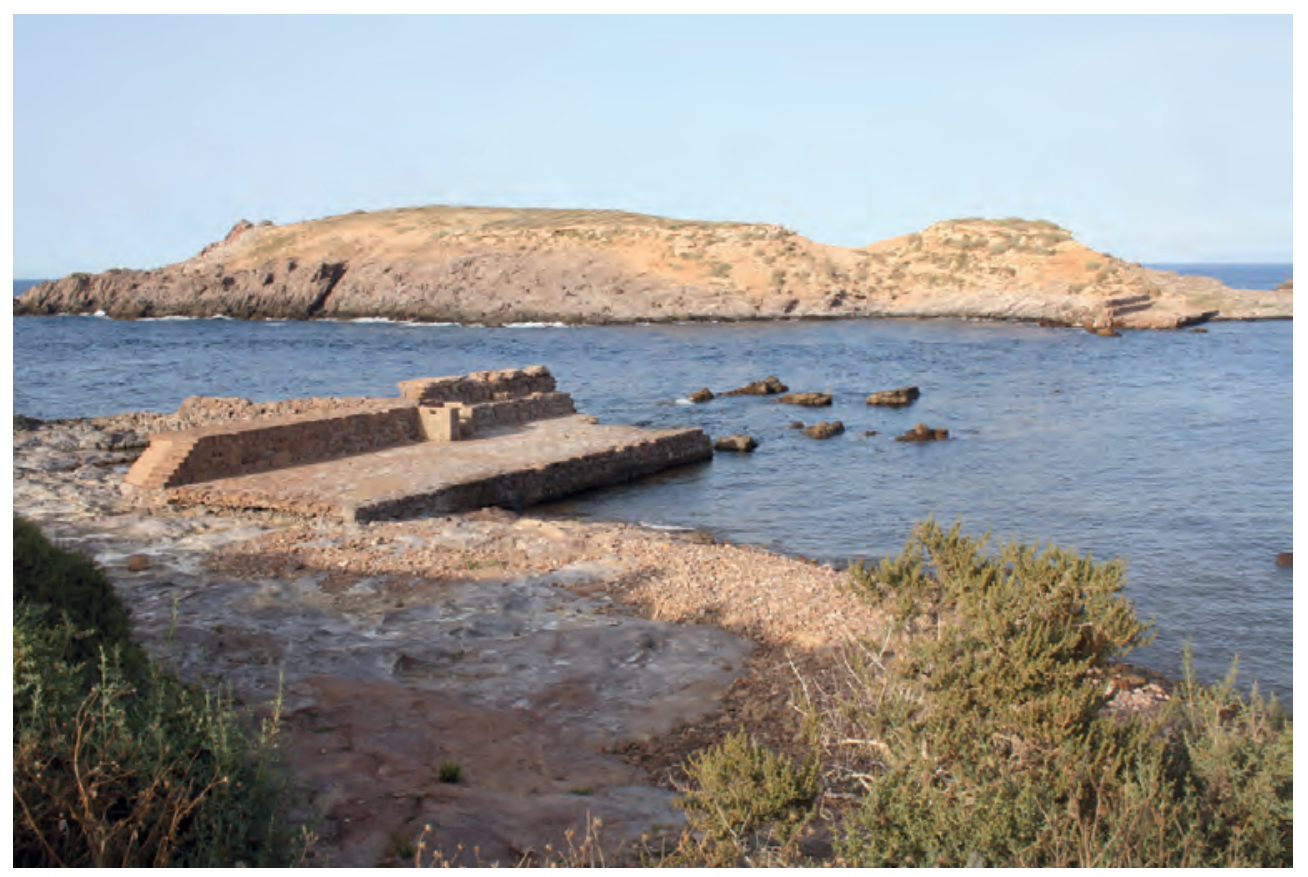

Dique noroeste en la actualidad. 


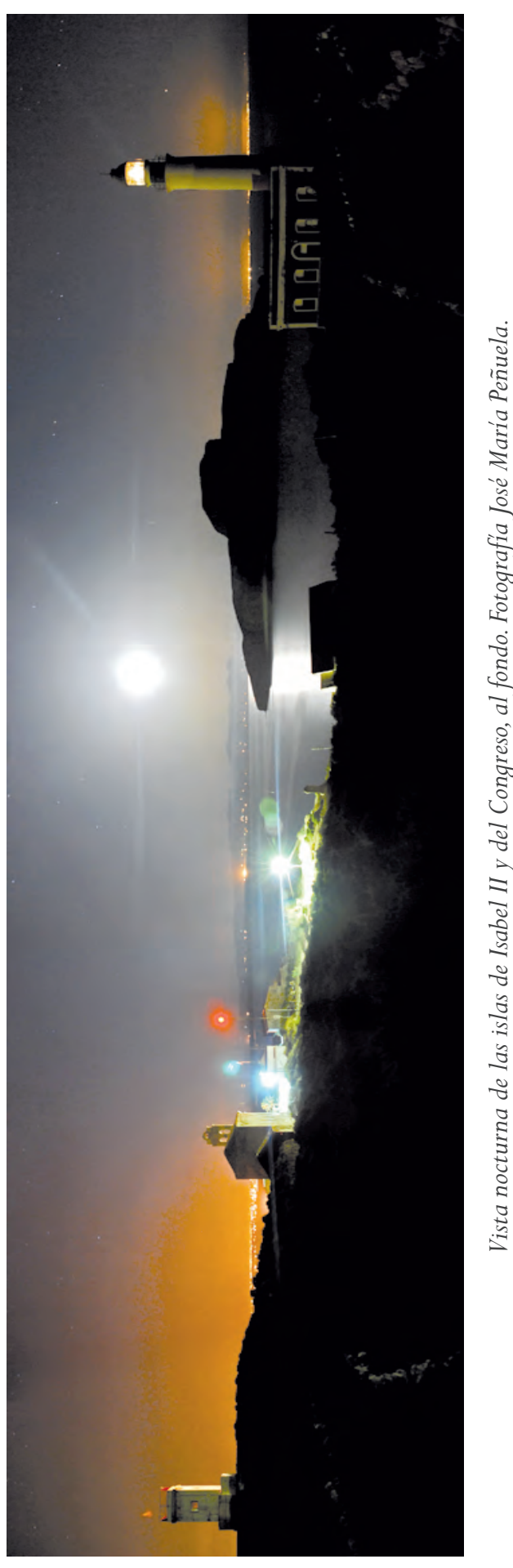




\section{BIBLIOGRAFÍA:}

- BARRERA, José Luis y PINED A, Antonio (2006). "Islas Chafarinas. La geología de un arc hipiélago deseado por todos”, Revista Tierra y Tecnología (Colegio Oficial de Geólogos), n 30; págs. 13 a 30.

- CARRILlO DEALBORNOZY GALBEÑO, Juan (2003). "La Real y Militar Orden de San Fernando y el Arma de Ingenieros”, Revista Memorial del Arma de Ingenieros, nº 63, diciembre, página 117.

- DOMINGUEZ LLOSÁ, Santiago (1984). «Breve historia de las Islas Chafarinas», Revista Aldaba, número 3. UNED-Melilla.

- LAFARGA CABIEDES, Francisco (1894). "Plazas españolas en África: plan de puertos, faros y valizas”, Revista de Obras Públicas, Núm. 20. Madrid.

- LÓPEZTIRADO, Jacinto (2002). Islas Chafarinas. Un paseo por su historia. Editorial Asociación de Estudios Hispano-Africanos. Melilla.

- MARIÑAS OTERO, Eugenio (1998). "Las Plazas Menores de soberanía en Áfr ica”, Revista de cultura militar; págs. 141-168.

- MINISTERIO DE MEDIO AMBIENTE. "La iglesia de la isla de "Isabel II en el RNC Islas Chafarinas". PáginaWeb. Refugio Nacional de Caza de las islas Chafarinas.

- MIR BERLANGA; Francisco (1980). "Las Islas Chafarinas. Historia del archipiélago de Chafarinas", Revista Jábega n 32 ; págs. 51-54.

- MOGA ROMERO, Vicente (1989). "Melilla \& las plazas menor es (Chafarinas; Vélez de la Gomera; Alhucemas) en el ÁDiccionario Geográfico- Estadístico-Histórico de España y sus posesiones de ultramarÈ (Madrid, 1845-1850) de Pascual Madoz", Revista Aldaba, número 13. UNED- Melilla. MORALES Y MEDICUTÍA, Gabriel de (1909). Datos para la Historia de Melilla (1497-1907). Melilla: El Telegrama del Rif.

- NARVAEZ LOPEZ, Francisco (2007). “El temporal de 1914. La Grúa Titán y el Dique Roto de Chafarinas” Memoria 2007. Autoridad Portuaria de Melilla.

- PUERTO DE MELILlA. “Memorias Anuales 1904-2008”. DVD. Autoridad Portuaria. Melilla, 2008.

- QUIRîS LINARES, Francisco (1998). “Los Peñones de Vélez de la Gomera y Alhucemas y las Islas Chafarinas”, Ería: Revista cuatrimestral de geografía, no 45; págs. 54-66.

- SÁNCHEZTERRY, Miguel Ángel (1993). Faros españoles del Mediterráneo. Servicio de Publicaciones del Ministerio de Fomento. Madrid.

Archivos:

Archivo Intermedio Militar de Melilla. COMGEMEL

Archivo General Militar de Madrid

Archivo Autoridad Portuaria de Melilla

Biblioteca Publica del Estado en Melilla

Biblioteca Nacional. Hemeroteca Digital

Instituto Nacional de Estadística

Archivo Central de Melilla

- Archivo Histórico Provincial de Málaga 